\section{To: (Receiving Organization) FFTF Engineering}

5. Proj./Prog./Dept./Div.:

FFTF

8. Originator Remarks:

Transmittal of HNF-1843, Health and Safety Consequences of Medical Isotope Processing at the Hanford Site 325 Building

11. Receiver Remarks: 11A. Design Basel ine Document? [] Yes [X] No

\author{
3. From: (originating organization) \\ Pacific Northwest Laboratory \\ 6. Design Authority/ Design Agent/Cog. \\ Engr.: \\ K. Rhoades
}

4. Related EDT No.:

$N / A$

7. Purchase Order No.:

N/A

9. Equip./Component No.:

$N / A$

10. System/Bidg./Facility: $N / A$

12. Major Assm. Dwg. No.: $N / A$

13. Permit/Permit Application No.: $N / A$

14. Required Response Date: November 19, 1997

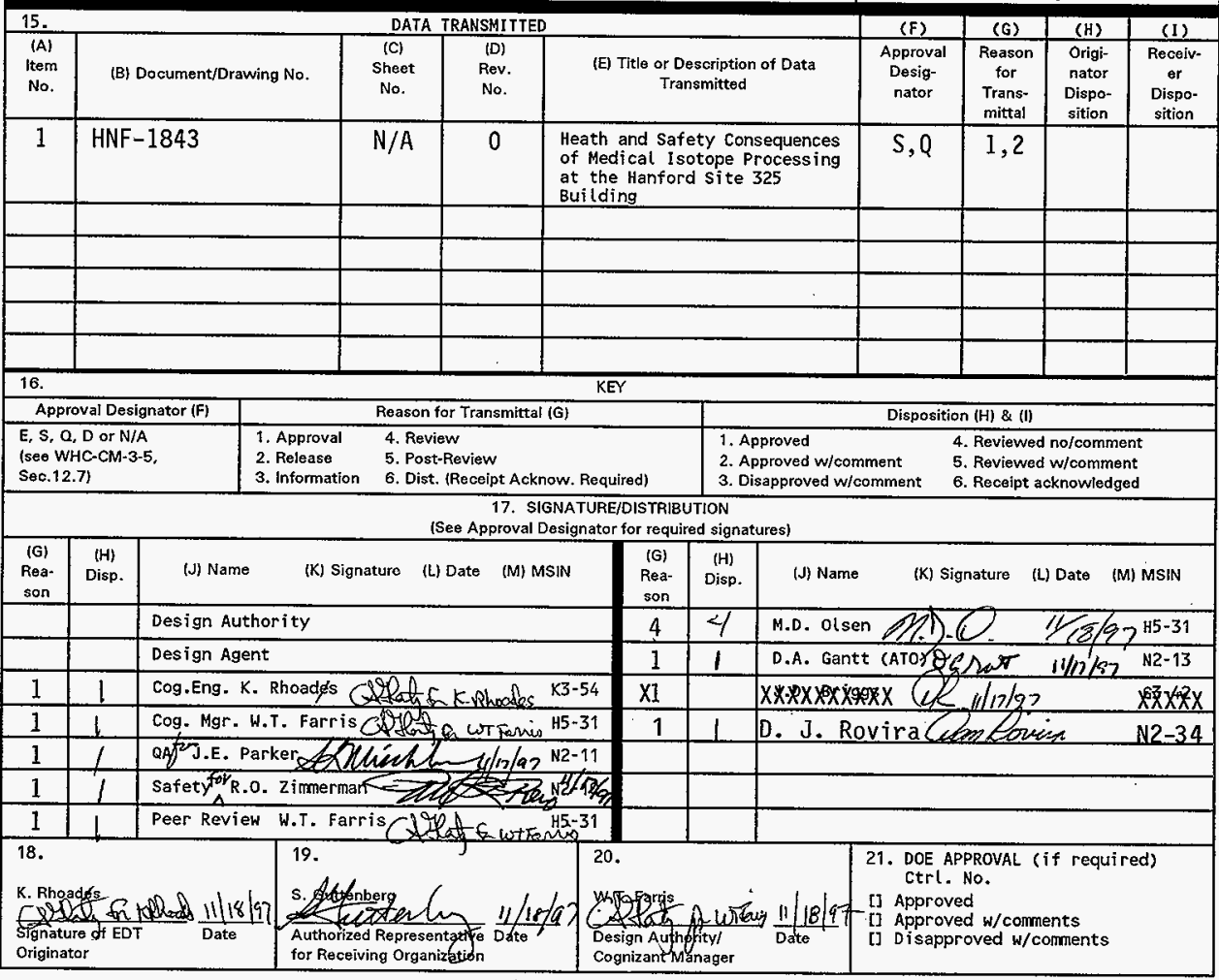

BD-7400-172-2 (05/96) GEF097 


\title{
Health and Safety Consequences of Medical Isotope Processing at the Hanford Site 325 Building
}

\author{
K. Rhoads, D.E. Lucas, L.H. Staven
}

Pacific Northwest National Laboratory, Richland, WA 99352

D. L. Nielsen

B \& W Hanford Company, Richland, WA 99352

U.S. Department of Energy Contract DE-AC06-96RL13200

EDT/ECN : 619615

Org Code: 18200

B\&R Code: EX7002000
UC: 507

Charge Code: BE2600

Total Pages: 43

Key Words: Medical Isotopes, 325 Building, Health and Safety

Abstract: A draft Technical Information Document (HNF-1855) is being prepared to evaluate proposed interim tritium and long-term medical isotope production at the Fast Flux Test Facility (FFfF). This assessment examines the potential health and safety impacts associated with the proposed processing in the 325 Building of medical isotope targets that have been irradiated in the FFTF. Bounding source terms were used. The routine health and safety consequences to workers and the public would be well within prescribed safety guidel ines. For facility and processing accidents, the resulting worker and public exposure for all credible events are projected to be within prescribed safety guidelines. These assessments are based on best information available at this time. This report will be revised using updated estimates of medical isotope production accident probabilities, and atmospheric dispersion conditions to support the development of a final revision to the Technical Information Document.

TRADEMARK DISCLAIMER. Reference herein to any specific comercial product, process, or service by trade name, trademark, manufacturer, or otherwise, does not necessarily constitute or imply its endorsement, recommendation, or favoring by the United States Government or any agency thereof or its contractors or subcontractors.

Printed in the United States of America. To obtain copies of this document, contact: Document Control Services, P.0. Box 950, Mailstop H6-08, Richland WA 99352, Phone (509) 372-2420; Fax (509) 376-4989.

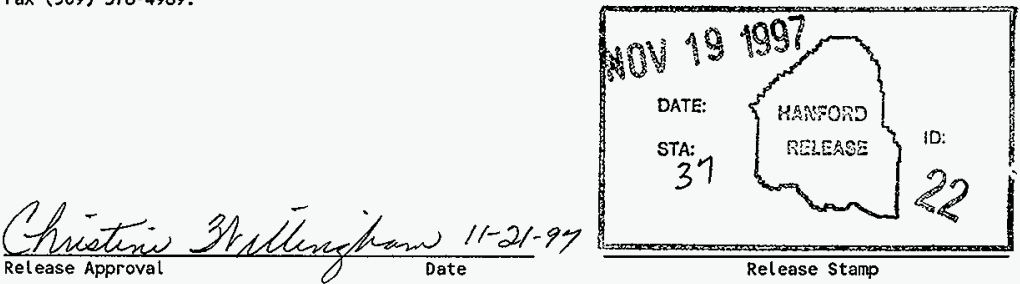

\section{Approved for Public Release}


HNF-1843, Rev. O

\section{Health and Safety Consequences of Medical Isotope Processing at the Hanford Site 325 Building}

\subsection{INTRODUCTION}

Potential activities associated with medical isotope processing at the Hanford Site 325 Building laboratory and hot cell facilities are evaluated to assess the health and safety consequences if these activities are to be implemented as part of a combined tritium and medical isotope production mission for the Fast Flux Text Facility (FFTF).

The types of activities included in this analysis are unloading irradiated isotope production assemblies at the 325 Building, recovery and dissolution of the target materials, separation of the product isotopes as required, and preparation of the isotopes for shipment to commercial distributors who supply isotopes to the medical community. Possible consequences to members of the public and to workers from both radiological and non-radiological hazards are considered in this evaluation.

Section 2 of this document describes the assumptions and methods used for the health and safety consequences analysis, section 3 presents the results of the analysis, and section 4 summarizes the results and conclusions from the analysis.

\subsection{METHODS AND ASSUMPTIONS FOR HEALTH AND SAFETY ANALYSIS}

The assumptions and methods used to estimate potential health and safety consequences of processing medical radioisotopes at the 325 Building are described in the following sections. In general, possible types of health consequences fall into two major categories -- those resulting from exposure to radionuclides, and nonradiological injuries or illnesses resulting from workplace accidents or exposure to hazardous chemicals. Radiological consequences result from exposure to radioactive materials that are produced in conjunction with the medical isotope mission. These materials may consist of some types of initial target material, impurities and activation products that result from irradiation of the targets, medical isotope products, and some waste materials.

\subsection{Assumptions for Medical Isotope Production}

The basic assumptions for medical isotope production used to evaluate the potential health consequences are summarized in Table 1 . The table includes a list of the 30 medical isotopes that are candidates for production at FFTF, associated target materials, and production quantities (based on target assembly capacity and projected market demand). With the 
exception of Ra-226, all of the targets are initially made from non-radioactive materials. Ra226 serves as the target material for Ac-227, Th-228, and Th-229. Irradiation times for isotopes produced in the rapid retrieval assemblies are assumed to be either 10,25 , or 50 days. The long irradiation assemblies may remain in the reactor for one or more operation cycles, which are assumed to last 100 days.

Following irradiation at FFTF, the medical isotope targets would be brought to the 325 Building for required processing and packaging for offsite shipment. Processing for most of the isotope targets would include removal of the target materials from the assembly cladding, dissolution of the target material, chemical separation of the product isotopes from the target material or other impurities when required, packaging of the product for shipment, and waste disposal.

In two cases, the product isotopes would be produced by irradiation of gaseous targets. I-125 would most likely be produced by circulating Xe-124 through the reactor core in a continuous loop. The I-125 would be trapped by an in-line filter that would periodically be removed and transported to the 325 Building. The I-125 would be transferred from the filter to an aqueous solution for further processing or distribution. For this analysis, the filters were assumed to be removed and processed up to 17 times per year. Xe-127 would also be produced from a xenon gas target encapsulated in long-term irradiation vehicle assemblies. Processing of that isotope would consist only of transferring it from the target pins to another suitable container for offsite shipment.

\subsection{Basis for Radiological Health Consequences}

The basis for estimating radiological health consequences is described in the following sections. Health consequences of exposure to radioactive materials can be divided into two general categories: 1) nonstochastic effects where the severity of the effects typically depend on the magnitude and duration of the exposure, and which occur at relatively high total doses, and 2) stochastic effects where the frequency or probability of the effect (rather than the severity of the effect) depends on the magnitude of the exposure, and which are manifested primarily at lower doses than those required to produce nonstochastic effects. Nonstochastic effects are assumed to occur only at doses above a specific threshold for each type of effect, whereas for radiation protection purposes, the risk of stochastic effects is assumed to be proportional to the dose even to very low levels. Examples of nonstochastic effects include reproductive sterility, cataracts, and depression of blood cell production. Examples of stochastic effects include radiation-induced cancers and genetic effects in offspring of exposed individuals. 
Estimating the frequency or probability of stochastic effects such as cancer is a two-step process. The first step is to estimate the radiation dose to an individual or population through all applicable exposure pathways. The second step converts the radiation dose to a frequency or probability of the health effect of interest using a conversion factor. The methods used to estimate radiation doses and potential health effects are described in the following sections.

\subsubsection{Radiological Dose Estimates}

Radioactive materials released to the environment may result in radiation doses to individuals that come into contact with them through a number of potential exposure pathways. Those typically considered for environmental dose assessments include external exposure to penetrating radiation (such as $\mathrm{x}$-rays or gamma rays) from radionuclides in the air, in water, or on the ground near the individual's location. Radioactive materials can also be taken into the body by inhaling radioactive material in the air, or by ingesting food or water that contains radionuclides.

External radiation exposure may also occur from exposure to sealed sources containing radionuclides that emit penetrating radiation. Regulatory requirements for management of such sources make exposure to members of the public via this mechanism very unlikely; however, this assessment does consider external exposure from irradiated medical isotope target assemblies to workers. The procedures used to estimate doses for environmental releases of radionuclides and direct exposure to radioactive sources are described in the following sections.

2.2.1.1 Basis for Radiation Dose Estimates. Radiation doses for this assessment were calculated according to methods recommended by the International Commission on Radiological Protection (ICRP)in Publications 26, 30, and 48 (ICRP 1977, ICRP 1979-1988, ICRP 1986). The GENII software system (Napier et al 1988), which implements these recommendations was used to model transport, exposure, intake and dose for radionuclides released to the atmosphere. Because processing of medical isotopes would not generate liquid effluents that are released to public waterways, exposure to waterborne radionuclides is not considered applicable for this analysis.

The MICROSHIELD software package (Worku and Negin 1995) is used to assess potential external exposure rates to involved workers from unshielded medical isotope assemblies during accidental events. MICROSHIELD calculates external dose rates for radioisotope sources with various source and shield geometries. For this analysis, workers are assumed to be located at an effective distance of $3 \mathrm{~m}$ from an unshielded medical isotope target assembly. The geometry of the source was assumed to be a cylinder with an effective volume and 
dimensions similar to those of either the rapid retrieval or long-term irradiation vehicle assembly used for each isotope.

2.2.1.2 Atmospheric Dispersion Airborne Emissions. Dispersion of radionuclides released to the atmosphere from the 325 Building stack, or from other possible exit points in the facility during accidents, are modeled using a straight-line Gaussian plume dispersion model as implemented in the GENII software system. The air transport models in GENII use a joint frequency distribution of wind speed, wind direction, and atmospheric stability to estimate downwind radionuclide air concentrations under both routine (chronic) and accidental (acute) release conditions. The meteorological data used for this assessment were collected at the 300 Area 10-m tower during the years 1983-1991 (Schreckhise et al 1993).

For routine emissions of radionuclides via the 325 Building stack, the air transport model in GENII was used to generate annual average air concentrations at the selected receptor locations. For accidental emissions during a relatively short event (less than 8 hours), bounding atmospheric dispersion conditions are assumed (those that generate pollutant concentrations that would be exceeded only $0.5 \%$ of the time in the given transport sector). Releases from the facility are assumed to occur at or below the building roof level, with a simple correction for building wake effects.

\subsubsection{Receptors Evaluated for Airborne Emissions. Receptors for estimating the} maximum impacts from routine emission included an on-site co-located worker, an individual off-site resident, and the population within $50 \mathrm{mi}(80 \mathrm{~km})$ of the 300 Area. The location for the on-site worker corresponds to the point of maximum, annual, ground-level impact from potential 325 Building emissions ( $300 \mathrm{~m} \mathrm{NE}$ of the facility stack). The location of the off-site resident corresponds to a similar maximum impact point for an off-site residence (on the east bank of the Columbia River, about $1500 \mathrm{~m} \mathrm{NE}$ of the 325 Building). Population impacts are calculated using population distribution information compiled from 1990 census data (Beck et al 1991) and are summarized in Table 2.

In the case of accidental radionuclide emissions to the atmosphere, doses are calculated for the maximally impacted co-located worker, the nearest access point (e.g., roadway, river bank, Site fenceline) for a member of the public, the maximally impacted off-site residential location, and the collective population within $50 \mathrm{mi}(80 \mathrm{~km})$ of the 300 Area. The co-located worker was evaluated at a point $100 \mathrm{~m}$ northeast of the 325 Building in the direction of the maximum short-term downwind air concentration. The publicly accessible location having the greatest short-term air concentration is $470 \mathrm{~m}$ west-northwest of the 325 Building. The maximum dose for an offsite resident is evaluated for a location about $1,300 \mathrm{~m}$ east-northeast of the facility, (on the far side of the Columbia River). The maximum collective dose to the offsite population is calculated assuming that the entire release is transported toward the direction that 
produced the highest collective exposure to airborne radionuclides. For accidental releases at the 300 Area, transport to the south produced the maximum collective population dose.

\subsubsection{Exposure Pathways Included in Dose Calculations for Airborne Emissions.} Exposure pathways for routine radionuclide emissions from the 325 Building included inhalation and external exposure via plume submersion and ground deposition for all receptors. Ingestion of locally grown food is also considered for the offsite individual resident and collective population. Exposure and consumption parameters for the routine emissions dose assessment are summarized in Table 3, and correspond to those recommended for use at Hanford in Schreckhise et al (1993).

Exposure pathways for accidental radionuclide releases to air are external exposure from plume submersion and inhalation during the entire plume passage at all receptor locations. External exposure from radionuclides deposited on the ground is evaluated for the duration of the plume passage in the case of the onsite worker and a member of the public at the nearest point of access. The individual off-site resident and the collective population within $50 \mathrm{mi}$ is assumed to be exposed to radionuclides on the ground surface for the entire year using an average effective outdoor exposure time. No protective actions are assumed other than evacuation of onsite personnel after the end of the event.

Doses from the ingestion pathway are also calculated for the off-site receptors to determine the extent to which protective actions (interdiction or quarantine of contaminated food, for example) might be required in the event of an accident. Ingestion doses are estimated for a release that occurs in the Winter, (minimum food contamination), and in the Autumn (maximum food contamination,) in order to calculate the range of consequences that might result. Doses from ingestion are reported separately from the inhalation and external pathway doses because DOE safety review guidelines do not apply to ingestion doses. Exposure and consumption parameters for the accident dose assessments are summarized in Table 4, and correspond to those recommended for the Hanford Site in Schreckhise et al (1993).

\subsubsection{Health Effects of Radiological Exposures}

Estimates of health consequences from radiological exposures to workers and the public are based on recommendations of the International Commission on Radiological Protection (ICRP 1991). The consequences in terms of latent cancer fatalities and total detrimental health effects are presented in Table 5 for both adult workers and the general population. The total incidence of detrimental health effects includes both fatal and nonfatal cancers and severe hereditary effects. The higher rates for health effects in the general population account for the presence of more sensitive individuals, such as children, compared with the relatively homogeneous population of healthy adults in the work force. 
The ICRP dose-to health effects conversion estimates are based on radiation exposures to relatively large populations at higher doses and dose rates, and by different pathways, than those normally encountered in the environment. In addition, the health effects coefficients in the table are based on collective doses to the entire exposed population. Collective dose is defined as the sum of doses to all individuals in the population, who may exhibit a wide range of susceptibility to radiation-induced health effects. The health effects coefficients are therefore associated with substantial uncertainty when applied to dose estimates for individuals, whose sensitivity may differ from the population average. However, the assumptions used to develop the health effects coefficients are sufficiently conservative that they would be "unlikely to underestimate the risks" (ICRP 1991).

Although DOE recommendations for NEPA documents favor presenting health risks in terms of potential radiation-induced cancer fatalities, recent investigations into the health effects.of low level radiation exposure have cast doubt on the utility of estimating radiation-induced health effects at very low environmental exposure levels. The Health Physics Society, an organization of over 6,800 radiation protection professionals, recently issued a position paper that made the following recommendation:

"In accordance with current knowledge of radiation health risks, the Health Physics Society recommends against quantitative estimation of health risk below an individual dose of 5 rem in one year or a lifetime dose of 10 rem in addition to background radiation. Risk estimation in this dose range should be strictly qualitative accentuating a range of hypothetical health outcomes with an emphasis on the likely possibility of zero adverse health effects. ... There is substantial and convincing scientific evidence for health risks at high dose. Below 10 rem (which includes occupational and environmental exposures), risks of health effects are either too small to be observed or are non-existent."

(Health Physics Society Newsletter, March 1996)

Although that position would not necessarily reflect the unanimous opinion of all the society's members, it does reflect the concern of radiation protection professionals that potential exposures to radiation for beneficial purposes should be placed in proper perspective. The quantitative risks presented in NEPA documents therefore provide a bounding estimate of the potential consequences, which in many cases are likely to be non-existent.

Risk, as defined for this analysis, refers to the potential health consequences of an activity to a population or an individual weighted by the frequency with which that activity, event, or consequence is expected to occur. Estimates of the latent cancer fatality (LCF) risk associated with routine operations assume that the consequences would occur; that is, the events that produce the dose to an individual or population have an expected frequency of 1.0 . 
In the case of accidents, the risk of LCF incorporates the expected frequency of the event that produces a potential dose, including the relative frequency of the atmospheric conditions that produce the estimated consequence. The atmospheric conditions that are used for the accident analyses produce downwind air concentrations that would be exceeded only $0.5 \%$ of the time. Those conditions are assumed to be $1 \%$ as likely as the "expected or mean" atmospheric conditions, which are typically at the 50th percentile. Therefore, the risks calculated for this analysis include both the frequency of the initiating event and the relative frequency of the bounding atmospheric conditions. The risk for radiological accidents is numerically equal to the hypothetical dose to an individual or population (if the event occurs) multiplied by the health effects coefficient for the endpoint of interest and the estimated event frequency. Risks for accidents are reported per year of operation where the expected duration of the proposed action is not known.

\subsection{Basis for Non-radiological Health Consequences}

Nonradiological risks to workers from occupational illness or injury are based on statistics for DOE and DOE contractor experience (DOE 1996). The average "total recordable case rate" for the years 1990-1994 was 4.1 per 200,000 worker hours. Using the standard assumption for DOE and contractors of 1830 hours per year for a full-time-equivalent worker (FTE), the average total recordable case rate amounts to about 0.038 per FTE, or about 1 for every 27 FTEs. The rates were somewhat higher for construction activities, which accounted for about $18 \%$ of the reportable cases and about $10 \%$ of the work force in 1995 (or about 1 case per 15 FTEs). Total recordable cases include all work-related deaths, illnesses, and injuries that impair worker performance or require medical treatment beyond first aid. Of DOE's total recordable cases in $1995,0.06 \%$ were fatalities, $45 \%$ were lost workday cases, and slightly less than $55 \%$ were nonfatal cases without lost work time.

In accordance with DOE policy that the level of analysis should be commensurate with the level of risk, consequences to workers and the public from routine exposure to hazardous chemicals are not evaluated in detail for the medical isotope processing. Although chemicals such as acids and solvents would be involved in preparation of some isotopes for shipment, the quantities of material in use at any time would be sufficiently small that they would not present a substantial risk. In addition, all activities would be conducted in fume hoods, glove boxes, or hot cells to control potential radionuclide releases. These controls would also serve to minimize worker and public exposures to hazardous materials that may be involved in the processes.

Accidental risks to workers from handling hazardous chemicals would be included in the overall risk of occupational illness or injury based on experience at DOE facilities, and which was used to evaluate those consequences. Because of the limited quantities of material in use 
during processing, accidents involving these materials are not expected to result in adverse consequences outside the immediate area. Therefore, consequences to workers outside the facility or to members of the public are not evaluated.

\subsection{RESULTS OF THE HEALTH AND SAFETY EVALUATION}

Potential exposures of workers and members of the public to radiological and non-radiological hazards were evaluated for both routine operations and potential accident scenarios during processing of medical isotopes. For routine operations and accidents that might result in air emissions, the releases were estimated from the radionuclide inventories that might be in process at any time (typically the inventory of a single rapid retrieval or long term irradiation target assembly). Because of the need to process and ship the short-lived isotopes quickly, the probability of more than one assembly undergoing processing simultaneously in the same area of the 325 building is relatively small. Release fractions for these materials during normal handling and postulated accident events are based on scenarios evaluated in the 325 Building Safety Analysis Report (SAR) for similar types of processes (PNNL 1997). The projected radionuclide inventories and emissions for both routine processing and accidents are listed in Table 6. Doses and risks were calculated for applicable receptors using the methods described in the previous section.

\subsection{Routine Radiological Consequences of Medical Isotope Processing at the Hanford Site 325 Building}

Potential air emissions from medical isotope target processing are estimated to determine the dose and consequences to co-located workers and members of the public. The potential emissions are based on a laboratory powder spill scenario in the 325 Building SAR (PNNL 1997) as a conservatively high estimate of the releases that might occur as a result of normal handling during processing of the target assemblies. Ventilation systems in all of the laboratories that could be used for medical isotope processing include at least two sets of tested HEPA filters. Therefore, the emission estimates include removal by both HEPA filters, assuming that the second filter operates at $10 \%$ of the tested particulate removal efficiency. The estimated release was calculated from the target radionuclide inventories, the respirable release fraction, and the HEPA removal efficiencies as follows:

$\begin{array}{ll}\text { Powder Spill Release Fraction } & =2 \mathrm{E}-3 \\ \text { Respirable Fraction } & =3 \mathrm{E}-1 \\ \text { HEPA Removal (stage 1) } & =5 \mathrm{E}-4 \\ \text { HEPA Removal (stage 2) } & =5 \mathrm{E}-3\end{array}$


$\begin{array}{ll}\text { Overall Release Fraction } & =1.5 \mathrm{E}-9 \\ \text { Release During Processing } & =1.5 \mathrm{E}-9 \times \text { Target Inventory }\end{array}$

The doses calculated for processing a single target were multiplied by the maximum number of targets that could be processed in a year to obtain the annual dose rates from target processing. For purposes of this analysis, it is assumed that up to three long term irradiation or 50 rapid retrieval targets of a single isotope type could be processed during a calendar year. In actual practice, it is implausible that these many targets of one type would be produced in a given year; however this analysis bounds the consequences that would occur for any possible mixture of isotopes that may actually be processed at the 325 Building.

Results of the analysis are presented in Table 7 for both a single target assembly and annual emissions during processing at the 325 Building. Processing Ra-226 targets results in the highest doses to an onsite worker (less than $4 \mathrm{E}-05 \mathrm{mrem} / \mathrm{y}$ ) with an associated latent cancer fatality (LCF) risk of about $2 \mathrm{E}-11$. For offsite residents, processing the Ra-226 targets resulted in a maximum individual dose of $7 \mathrm{E}-05 \mathrm{mrem} / \mathrm{y}$ and $4 \mathrm{E}-11$ risk of LCF. This dose is well below the 40 CFR 61 regulatory standard of $10 \mathrm{mrem} /$ year for DOE facilities. The corresponding collective dose to the population was about $1 \mathrm{E}-03$ person-rem/y and the associated LCF risk was about $6 \mathrm{E}-07$ (less than 1 in $1,000,000$ ).

\subsection{Routine Radiological Exposure to Involved Workers from Medical Isotope Target Processing}

Radiological doses to DOE workers are limited to $5 \mathrm{rem} / \mathrm{yr}(0.05 \mathrm{~Sv} / \mathrm{yr})$ EDE by standards in $10 \mathrm{CFR}$ Part 835 , and in practice they are typically controlled to $0.5 \mathrm{rem} / \mathrm{yr}(0.005 \mathrm{~Sv} / \mathrm{yr})$ by site-specific administrative procedures unless special justification and approval are obtained. During 1995, the collective dose to workers in the 325 Building laboratories, including the shielded facilities, was about 10 person-rem ( 0.10 person-Sv), or an average of $0.1 \mathrm{rem} / \mathrm{y}$ $(0.001 \mathrm{~Sv} / \mathrm{yr})$ for the 100 workers employed in the facility. The 325 Building average worker dose was similar to the Hanford Site average for workers with a measurable (i.e., non-zero) dose during 1995 , which was $0.12 \mathrm{rem}(0.0012 \mathrm{~Sv})$. Assuming that up to 12 workers would be involved in medical isotope target processing, and that they would experience similar radiological doses, their collective dose would be less than 2 person-rem/yr $(0.02$ person$\mathrm{Sv} / \mathrm{yr}$ ). At the maximum, 12 workers exposed at the $0.5 \mathrm{rem} / \mathrm{y}$ administrative limit would accumulate a collective dose of 6 person-rem/y. 
HNF-1843, Rev. 0

\subsection{Potential Radiological Accidents at 325 Building During Medical Isotope Processing}

The accident analysis included identification of a set of potential accidents that could occur at the 325 Building during medical isotope processing, based on scenarios evaluated in the 325 Building SAR for similar types of processes (PNNL 1997). The set of accidents evaluated for the SAR was selected using a standard Preliminary Hazards Analysis (PHA) to identify the potential hazardous conditions in facility operations and to determine the significance of potential accidents. The types of events considered in the SAR included operator errors and handling accidents, fires and explosions, natural phenomena such as seismic events, criticality, and external events such as loss of support services. Events that were demonstrated to have a frequency less than 1 in 1 million are considered incredible and are not evaluated in detail in the SAR or in this document. The potential for an aircraft impact on the facility is evaluated in the SAR and is found to fall into the incredible frequency category.

For this analysis, one bounding accident scenario is identified in each of the frequency categories evaluated in the SAR (anticipated, unlikely, or extremely unlikely) in order to identify the events that result in both maximum consequence and maximum risk to onsite and offsite receptors. All types of events that could potentially apply to medical isotope processing are evaluated to determine which scenarios could result in the maximum radionuclide release for each frequency category. The analysis is intended to provide a conservative estimate for the potential consequences of the proposed activities, and any new processes would be subjected to a complete safety analysis before implementation to ensure compliance with all applicable safety guidelines and standards. In addition, safety guidelines for the 325 building are established to limit the risk from accidents considering all activities in the building. Events that may cause concurrent emissions from more than one area or activity in the building are evaluated to control the maximum quantity of material "at risk" from all ongoing activities and maintain overall risks for the facility within safety guidelines.

Potential accidental releases of radioactive materials during medical isotope processing are estimated using projected radionuclide inventories for the target systems most likely to be considered for production of medical isotopes in FFTF. Release fractions for the radionuclides are calculated using the same assumptions as those used for similar types of materials in the SAR scenarios. The following section contains a description of the accident scenarios and the pertinent assumptions used to estimate the radionuclide emissions and receptor doses for each case. 
HNF-1843, Rev. 0

\subsubsection{Anticipated Category Events}

The 325 Building SAR identified a number of accident scenarios that fall into the "anticipated" frequency category (frequency greater than 0.01 per year). The types of accidents that fell into this category included the following:

- Localized Solvent Fire,Localized Solid Fire,

- Spill in a Hot Cell, and

- Spill in a Laboratory.

Of these events, the applicable scenario with the highest radionuclide release was the solvent fire.

A localized fire of sufficient severity to produce radionuclide releases is estimated to occur no more than once in 10 years. The upper bound frequency of such an event was supported by the fire loss history at Hanford over a 45-year period, during which time the site experienced 10 fires that resulted in significant property loss. Of those fires, 6 potentially involved radioactive materials, and 2 of the 6 events occurred in laboratory facilities. No fires of that magnitude have occurred in the 325 Building since it was occupied in 1953, and they would not be expected to occur routinely in that facility because of the facility design, administrative controls on conduct of operations, and the fire protection program.

The heating, ventilation, and air conditioning (HVAC) system is assumed to be operating during and after the fire. Combustibles (e.g. solvent-soaked rags) are assumed to be present in sufficient quantity to support combustion. The source terms used in this accident scenario were based on radioactive materials representative of anticipated medical isotope processing activities in the hot cells and other laboratories in the facility. Manual fire suppression is assumed not to occur or to be ineffective.

The final HEPA filters are assumed to be unaffected by the fire because they are located in a facility separate from the 325 Building. This assumption is based on the observations that the primary filters would stop most smoke particles and that air dilution would cool the hot gases leaving the laboratory or hot cell so the final HEPA filter bank would not be subjected to extreme temperatures. Therefore, the final stage of HEPA filters is assumed to remain intact. Particle deposition along the release path is not assumed to occur. The radon hold-up system is assumed to be ineffective, and it is also assumed that deposition or filtration of radioiodine or other noble gases would not occur. 
The radionuclide releases for this event, as estimated in the SAR, are assumed to involve radioactive solutions. Although many of the processes for preparing medical isotopes would involve only dissolution in aqueous acid solution, some of the chemical separations could require solvent extraction or ion exchange apparatus. Separate respirable release fractions (RRFs) are calculated for nonvolatile materials, volatile materials (iodine), and gases (tritium and noble gases) as follows:

Nonvolatiles RRF $=5 \mathrm{E}-6$

Respirable release fraction $=0.01$

HEPA particulate removal (nonvolatiles) $=5 \mathrm{E}-4$

Volatiles (I) RRF $=1.0$

Respirable release fraction $=1.0$

No removal by building deposition or emission control systems

Gas RRF $=1.0$

Respirable release fraction $=1.0$

No removal by building deposition or emission control systems

The consequences of this event for medical isotope target processing are presented in Table 8 . Hanford Site review criteria for anticipated events set a maximum dose of 5 rem for onsite workers and $0.5 \mathrm{rem}$ for members of the public. The anticipated category event resulting in the maximum exposure would be a localized fire. The hypothetical maximum doses for the co-located worker and the individual at the nearest public access location would be 2 and 0.2 rem, respectively (from a release of I-125). Only the inhalation and external exposure pathways are considered because no food is produced at these receptor locations. The hypothetical maximum doses to an offsite resident and the collective population dose would 0.2 rem and 3,000 person-rem, respectively (from a release of I-131).

Doses from the ingestion pathway are used to determine the extent to which protective actions (interdiction or quarantine of contaminated food, for example) might be required in the event of an accident. The maximum ingestion doses for an anticipated event occurs for a release of Iodine-125.

\subsubsection{Unlikely Category Events}

Events in the unlikely frequency category (frequency between $1 \mathrm{E}-4$ and $1 \mathrm{E}-2$ per year) for the 325 Building SAR included:

- Liquid Waste Cask Failure and Spill and 
HNF-1843, Rev. 0

- Unlikely Seismic Event.

In addition, the localized solvent fire and solid fire can occur in this frequency range. Of these scenarios, the unlikely seismic event resulted in a higher radionuclide release. Earthquake hazard curves have been developed for the 300 Area that define ground acceleration at the 325 Building for a given frequency. The seismic event analyzed in this section has a peak horizontal ground acceleration of $0.139 \mathrm{~g}$ for a frequency range of $1 \mathrm{E}-04$ to $1 \mathrm{E}-02$ per year. For earthquakes in the Unlikely category, a single potential process upset is assumed, but it is estimated that multiple major upsets would not occur. The facility's superstructure was assumed to remain intact, but the HVAC system is assumed to fail because it has not been seismically qualified.

This event is assigned to the Unlikely frequency category due to the return period of the initiating earthquake. Spilling of the powdered contents of one in-process medical isotope target is assumed to occur (that is, probability of the spill given that the seismic event occurs is assumed to be 1.0). The release quantity from the spill and holdup release is reduced by $50 \%$ to account for deposition of the powder within the facility. This $50 \%$ building removal factor could be applied to this scenario because of essentially static conditions that result from the failure of the ventilation system and blockage of airflow resulting from debris. Because this event does not involve a heat source to mobilize volatile materials, the RRF is assumed to be the same for all materials except noble gases. The radon holdup system is assumed to be ineffective for this scenario.

$$
\begin{aligned}
& \text { Powder Spill RRF }=3 \mathrm{E}-4 \\
& \text { Release fraction }=0.002 \\
& \text { Respirable fraction }=0.3 \\
& \text { Building removal factor }=0.5
\end{aligned}
$$

Gas RRF $=1.0$

Respirable release fraction $=1.0$

No removal by building deposition or emission control systems

Consequences of this event are summarized in Table 9. Hanford Site review criteria for unlikely events set a maximum dose of 25 rem for onsite workers and 5 rem for members of the public. The hypothetical maximum doses for the co-located worker and the individual at the nearest public access location would be 8 and 1 rem, respectively (from a release of I-125). The hypothetical maximum doses to an offsite resident and the collective population dose would 0.8 rem and 14,000 person-rem, respectively (from a release of I-131). If ingestion pathways are considered for planning protective actions, releases of $\mathrm{I}-125$ produce the greatest impacts. 
HNF-1843, Rev. 0

\subsubsection{Extremely Unlikely Category Events}

The 325 Building SAR identified the following events in the extremely unlikely category (frequency between $1 \mathrm{E}-6$ and $1 \mathrm{E}-4$ per year):

- Loss of Electric Power and Explosion,

- Large Uncontrolled Fire, and

- Extremely Unlikely Seismic Event.

Of these scenarios, the highest radionuclide release is associated with the loss of services followed by an explosion. This scenario assumes loss of services to the 325 Building, which inactivates the ventilation system. Upon failure of the ventilation systems, airflow through the hot cells, glove boxes, hoods, and tanks would also cease. Without ventilation, the potential exists for a buildup of flammable or combustible vapors in those areas with volatile chemicals. A deflagration in a glove box from the buildup of a flammable solvent or volatile chemical is assumed to occur, potentially breaching the primary confinement barriers. The impact of an explosion would be mitigated by the walls and ceilings of the glove box or fume hood. Most of the airborne material within a glove box or hood would be carried out through the exhaust system, even if the explosion were to cause material to be released from the glove box to an adjoining area. Based on actual glove box explosions, it is possible that the front panel of a glove box could fail. In most cases, these events have not resulted in offsite releases because the explosions did not cause malfunctions of ventilation systems or failure of other barriers, including room walls and ceilings. However, for the extremely unlikely scenario in this analysis, the explosion is assumed to be sufficiently forceful to breach the building or ventilation system barriers, rendering the HEPA filters and radon hold-up system ineffective. The estimated RRF for this event was calculated as follows:

Powder RRF $=0.02$

Release fraction $=5 \mathrm{E}-2$

Respirable fraction $=0.4$

Volatiles (I) RRF $=1.0$

Respirable release fraction $=1.0$

No removal by building deposition or emission control systems

Gas RRF $=1.0$

Respirable release fraction $=1.0$

No removal by building deposition or emission control systems

The consequences of this event as summarized in Table 10. Hanford Site review criteria for extremely unlikely events set a maximum dose of 100 rem for onsite workers and 25 rem for 
members of the public. The hypothetical maximum doses for the co-located worker and the individual at the nearest public access location would be 65 and 8 rem, respectively (from a release involving an Ra-226 target). The hypothetical maximum doses to an offsite resident and the collective population dose would 4 rem and 40,000 person-rem, respectively. If ingestion pathways are considered for planning protective actions, the release of I- 125 would produce the greatest impacts.

\subsubsection{Accident Consequences to Involved Workers}

Accident consequences to involved workers are typically not evaluated in Safety Analyses because the scenarios are highly dependent on circumstances of the event and the location and actions of individuals involved. In order to provide a bounding estimate of the potential dose to an involved worker, a generic isotope assembly handling accident has been evaluated in which a worker is exposed at a distance of $3 \mathrm{~m}$ to external irradiation from an unshielded irradiated medical isotope assembly. The external dose rate for each type of assembly has been estimated, and the time required to reach the 25 or 100 rem DOE review criteria for onsite workers in unlikely or extremely unlikely events is calculated. The 25 rem criteria also corresponds to the maximum allowable dose for workers in 10 CFR 835 under emergency conditions to protect life or to prevent exposure of large populations to accidental emissions. Dose rates are calculated separately for cladding material and for the isotope products and associated impurities within the assembly. As a bounding case, the cladding material was assumed to be 316 stainless steel, although other possible alloys would likely result in lower quantities of activation products and lower dose rates.

For this hypothetical accident, the maximum dose rate would result from events involving Gd153 or Ir-192 assemblies, exclusive of cladding. The minimum evacuation time available for events involving those assemblies is 15 seconds and 1 minute at the 25 and 100 rem criteria, respectively (Table 11). All other isotope product assemblies would require an exposure time of 10 minutes or longer to accumulate a dose of $100 \mathrm{rem}$. If stainless steel cladding is used for the assemblies, external doses from the activated cladding would reach the 100 rem level in $\mathbf{5 0}$ minutes for rapiḍ retrieval assemblies or 50 seconds for long-term irradiation vehicle assemblies.

\subsection{Worker Risk from Occupational Illness or Injury}

The risk of occupational injury or illness to facility workers is based on the labor requirements for the Proposed Action and recordable case rates for DOE contractors. The labor requirements for medical isotope target processing are estimated at less than 6 FTEs. These labor requirements are well below the DOE average 27 FTEs overall or 15 FTEs for 
construction that correspond to one recordable case of occupational injury or illness.

Therefore, no recordable illnesses or injuries are expected as a result of processing medical isotope assemblies.

\subsection{SUMMARY OF RISKS ASSOCIATED WITH MEDICAL ISOTOPE PROCESSING AND DISCUSSION OF POTENTIAL MITIGATION MEASURES}

The risks of health effects from accidental radiological releases during medical isotope processing at the 325 Building are projected to be less than 1E-04 for on-site workers, less than $3 \mathrm{E}-6$ for an individual member of the public, and less than $8 \mathrm{E}-03$ for the collective population. The doses to individual workers and members of the public for accidents involving several of the irradiated isotope assemblies are within DOE review criteria.

Prior to beginning the proposed activity, medical isotope processing would be subjected to a detailed safety review to ensure that activities would meet the DOE safety review criteria. Where more than one activity within the facility might be affected by an event, the consequences from all of the potentially affected areas would be evaluated to ensure that the cumulative effects would not exceed the safety criteria.

For the medical isotope assemblies that produce the highest doses, administrative or engineering controls could be implemented to maintain the potential consequences well within guidelines.

Collective risks to the population near the 300 area are also evaluated with respect to the safety goals established in Secretary of Energy Notice (SEN) 35-91 (DOE 1991). The SEN-35-91 safety goal for risk of latent cancer fatalities (LCF) in the general population is as follows:

"The risk to the population in the area of a DOE nuclear facility for cancer fatalities that might result from operations should not exceed one-tenth of one percent $(0.1 \%)$ of the sum of all cancer fatality risks resulting from all other causes. For evaluation purposes, individuals are assumed to be located within 10 miles of the site boundary."

For the 30,400 persons within 10 miles of the Hanford Site's 300 Area, this safety goal corresponds to an annual latent cancer fatality risk of about 50 LCF. The basis for this sitespecific estimate is the 1996 cancer fatality rate from all causes in Washington State $(165,000$ LCF 100,000 persons-year, from ACS 1996) and the 1990 census for the population surrounding the Hanford Site (Beck et al 1991). The SEN 35-91 safety goal for population risk is $0.1 \%$ of normal population LCF, or 0.05 LCF per year of operation for this population. The collective risks in this analysis are calculated for the population within 50 miles of the site 
HNF-1843, Rev. 0

and all are lower than $0.008 \mathrm{LCF}$ per year. Therefore the collective risks meet the SEN 3591 safety goal. 
HNF-1843, Rev. 0

Table 1. Assumptions and Data for Medical Isotope Production

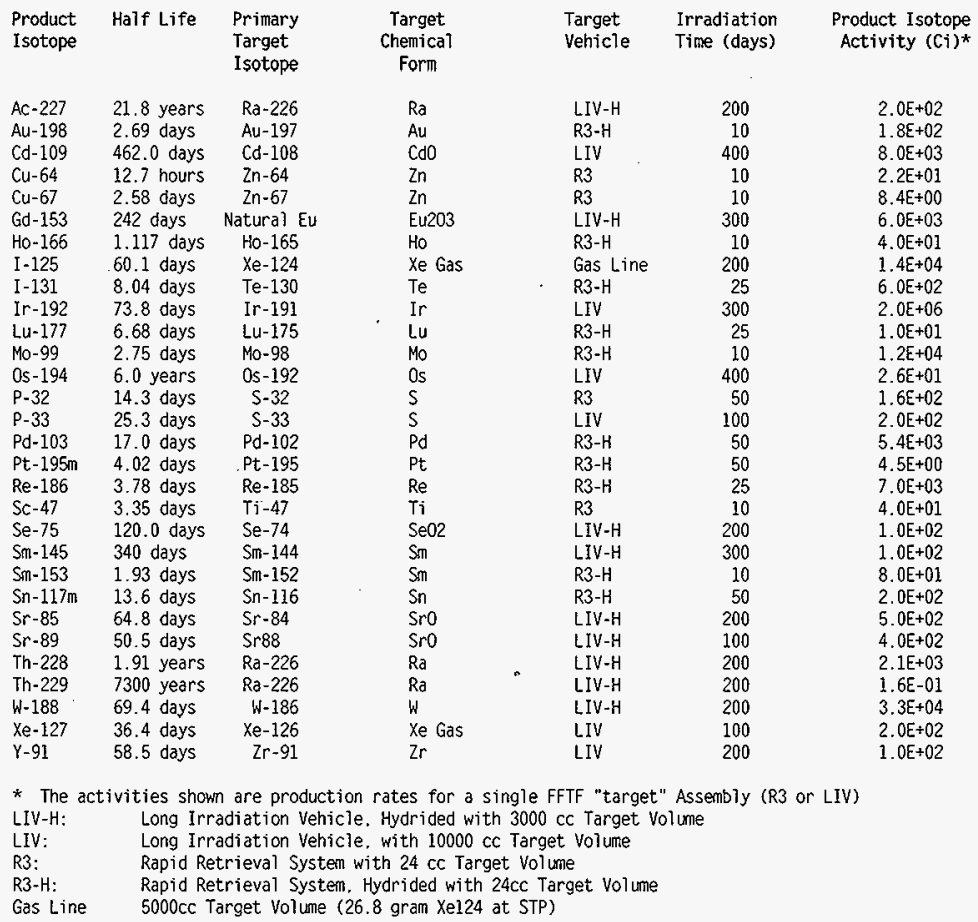


HNF-1843, Rev. 0

Table 2. Population within $80 \mathrm{~km}$ of the Hanford 300 Area

\begin{tabular}{|c|c|c|c|c|c|c|c|c|c|c|c|}
\hline $\begin{array}{l}\text { Distance (mi } \\
\text { Direction }\end{array}$ & 0.1 & 1.2 & $2-3$ & 3.4 & $4-5$ & $5 \cdot 10$ & $10-20$ & $20 \cdot 30$ & 30.40 & $40 \cdot 50$ & Sector Total \\
\hline S & 0 & 0 & 3 & 198 & 2231 & 17726 & 12449 & 123 & 13473 & 10913 & 57116 \\
\hline SSW & 0 & 0 & 0 & 0 & 297 & 3518 & 3788 & 288 & 651 & 1859 & 10401 \\
\hline SW & 0 & 0 & 0 & 0 & 59 & 2364 & 2916 & 1619 & 311 & 763 & 8032 \\
\hline WSW & 0 & 0 & 0 & 0 & 0 & 967 & 3238 & 5812 & 13516 & 713 & 24246 \\
\hline W & 0 & 0 & 0 & 0 & 0 & 0 & 730 & 1669 & 16968 & 12843 & 32210 \\
\hline WWW & 0 & 0 & 0 & 0 & 0 & 0 & 0 & 417 & 1703 & 2120 & 4240 \\
\hline NW & 0 & 0 & 0 & 0 & 0 & 0 & 0 & 181 & 1279 & 1428 & 2888 \\
\hline NNW & 0 & 0 & 0 & 0 & 0 & 0 & 0 & 273 & 1277 & 1153 & 2703 \\
\hline $\mathrm{N}$ & 0 & 0 & 0 & 2 & 6 & 85 & 602 & 4203 & 2894 & 9998 & 17790 \\
\hline NNE & 0 & 3 & 16 & 25 & 33 & 277 & 678 & 2242 & 2411 & 1218 & 6903 \\
\hline NE & 1 & 11 & 18 & 25 & 33 & 277 & 827 & 1094 & 590 & 306 & 3182 \\
\hline ENE & 2 & 11 & 18 & 25 & 33 & 277 & 754 & 741 & 480 & 535 & 2876 \\
\hline$E$ & 3 & 11 & 18 & 25 & 33 & 276 & 170 & 255 & 761 & 1001 & 2553 \\
\hline ESE & 2 & 11 & 18 & 25 & 33 & 264 & 117 & 454 & 878 & 10548 & 12350 \\
\hline SE & 2 & 11 & 18 & 25 & 33 & 277 & 15318 & 3337 & 1322 & 3257 & 23600 \\
\hline SSE & 0 & 7 & 18 & 25 & 121 & 616 & 57047 & 4098 & 3779 & 4785 & 70496 \\
\hline Total & 10 & 65 & 127 & 375 & 2912 & 26924 & 98634 & 26806 & 62293 & 63440 & 281586 \\
\hline
\end{tabular}


HNF-1843, Rev. 0

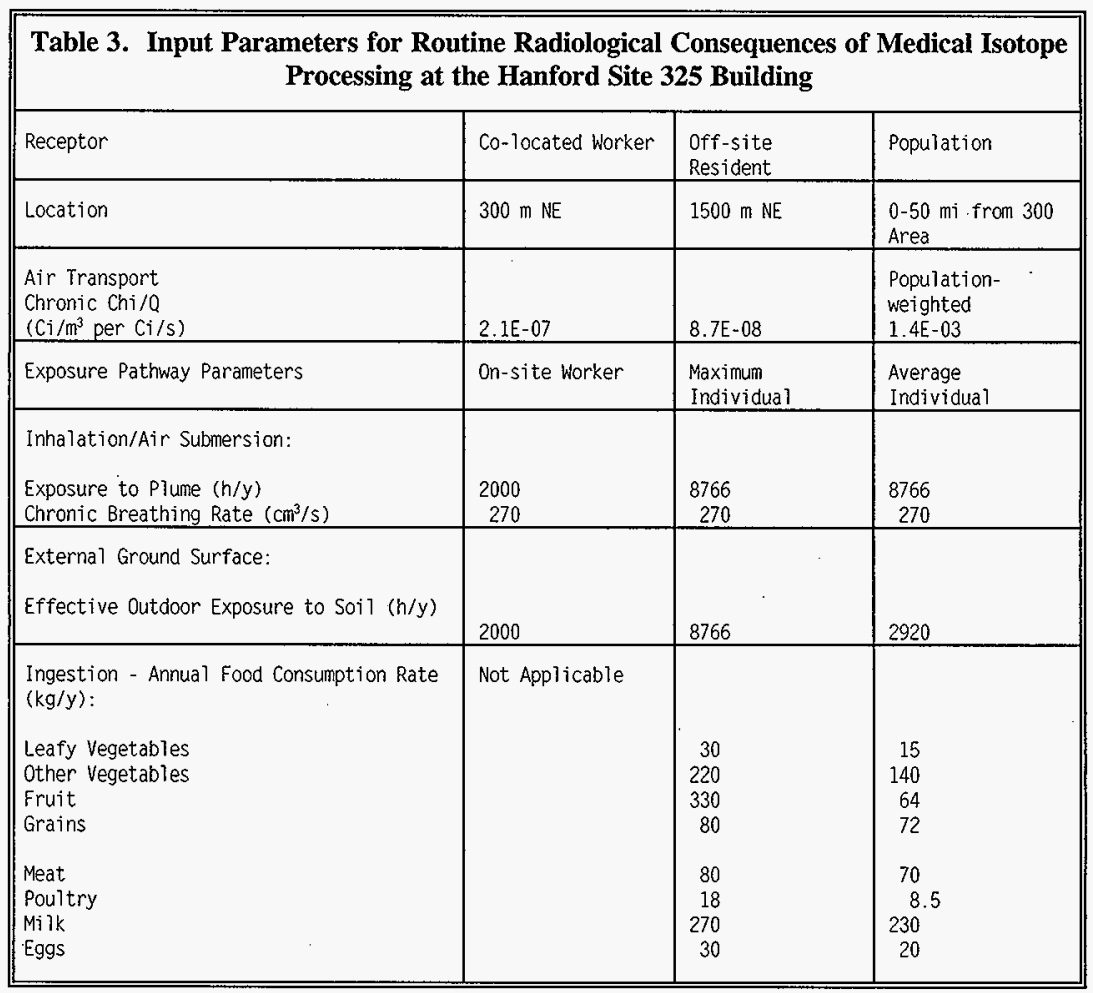


HNF-1843, Rev. 0

\begin{tabular}{|c|c|c|c|c|}
\hline Receptor & $\begin{array}{l}\text { Co-located } \\
\text { Worker }\end{array}$ & $\begin{array}{l}\text { Nearest } \\
\text { Public } \\
\text { Access }\end{array}$ & $\begin{array}{l}\text { Offsite } \\
\text { Resident }\end{array}$ & Population \\
\hline Location & $100 \mathrm{~m} \mathrm{NE}$ & $470 \mathrm{~m}$ WNW & $1300 \mathrm{~m}$ ENE & $\begin{array}{l}0-50 \mathrm{mi} \text { from } 300 \\
\text { Area }\end{array}$ \\
\hline $\begin{array}{l}\text { Air Transport } \\
\text { Acute Chi } / Q \\
\left(\mathrm{Ci} / \mathrm{m}^{3} \text { per } \mathrm{Ci} \text { released }\right)\end{array}$ & 1. $1.3 \mathrm{E}-03$ & $1.6 \mathrm{E}-04$ & $7.8 \mathrm{E}-05$ & $\begin{array}{l}\text { Population- } \\
\text { weighted } \\
8.0 \mathrm{E}-01\end{array}$ \\
\hline Exposure Pathway Parameters & On-site Worker & $\begin{array}{l}\text { Public } \\
\text { Access }\end{array}$ & $\begin{array}{l}\text { Maximum } \\
\text { Individual }\end{array}$ & $\begin{array}{l}\text { Average } \\
\text { Individual }\end{array}$ \\
\hline $\begin{array}{l}\text { Inhalation/Air Submersion: } \\
\text { Fraction of Time in Plume } \\
\text { Acute Breathing Rate }\left(\mathrm{cm}^{3} / \mathrm{s}\right)\end{array}$ & $\begin{array}{l}1.0 \\
330 \\
\end{array}$ & $\begin{array}{l}1.0 \\
330 \\
\end{array}$ & $\begin{array}{l}1.0 \\
330 \\
\end{array}$ & $\begin{array}{l}1.0 \\
330 \\
\end{array}$ \\
\hline $\begin{array}{l}\text { External Ground Surface: } \\
\text { Effective Outdoor Exposure to Soil } \\
\text { (h) }\end{array}$ & 2 & 2 & 4380 & 2920 \\
\hline $\begin{array}{l}\text { Ingestion - Annual Food Consumption } \\
\text { Rate }(\mathrm{kg} / \mathrm{y}) \text { : } \\
\text { Leafy Vegetables } \\
\text { Other Vegetables } \\
\text { Fruit } \\
\text { Grains } \\
\text { Meat } \\
\text { Poultry } \\
\text { Milk } \\
\text { Eggs }\end{array}$ & NA & NA & $\begin{array}{r}30 \\
220 \\
330 \\
80 \\
\\
80 \\
18 \\
270 \\
30\end{array}$ & $\begin{array}{c}15 \\
140 \\
64 \\
72 \\
70 \\
8.5 \\
230 \\
20\end{array}$ \\
\hline
\end{tabular}


HNF-1843, Rev. 0

\begin{tabular}{|c|c|c|}
\hline Type of Effect & Effects per Unit Radiation Dose ${ }^{a}$ & $\begin{array}{l}\text { Radiation Dose to Produce } 1 \\
\text { Effect }^{\mathrm{a} .}\end{array}$ \\
\hline $\begin{array}{l}\text { Latent Cancer Fatality } \\
\text { Adult Workers } \\
\text { General Population }\end{array}$ & $\begin{array}{l}4 \times 10^{-4} \text { /person-rem } \\
5 \times 10^{-4} \text { /person-rem }\end{array}$ & $\begin{array}{l}2500 \text { person-rem } \\
2000 \text { person-rem }\end{array}$ \\
\hline $\begin{array}{l}\text { Total Detriment } \\
\text { Adult Workers } \\
\text { General Population }\end{array}$ & $\begin{array}{l}5.6 \times 10^{-4} \text { /person-rem } \\
7.3 \times 10^{-4} \text { /person-rem }\end{array}$ & $\begin{array}{l}1800 \text { person-rem } \\
1400 \text { person-rem }\end{array}$ \\
\hline
\end{tabular}

- These estimates include a reduction factor of 2 to account for the lower risk of low dose, low dose rate exposures as discussed in ICRP (1991). Where individual doses exceed 20 rem, the values should be multiplied by a factor of 2. To convert person-rem to person-Sv, multiply by 0.01 .

- Total Detriment includes fatal and nonfatal cancers and severe hereditary effects. 
HNF-1843, Rev. 0

Table 6. Medical Isotope Inventories and Estimated Releases

\begin{tabular}{|c|c|c|c|c|c|c|}
\hline Isotope & $\begin{array}{l}\text { Max. } \\
\text { Quantity } \\
\text { of } \\
\text { Isotopes } \\
\text { Processed } \\
\text { at Any } \\
\text { One Time } \\
\text { (Ci) }\end{array}$ & $\begin{array}{l}\text { Irradiation } \\
\text { Vehicle }\end{array}$ & Anticipated & clide Rele & $\begin{array}{l}\text { Extremely } \\
\text { Unlikely }\end{array}$ & $\begin{array}{c}\text { Chronic } \\
\text { Release (Ci } \\
\text { per } \\
\text { Processing) }\end{array}$ \\
\hline P 32 & $1.60 \mathrm{E}+02$ & R3 & $8.0 E-04$ & 4. $8 \varepsilon-02$ & $3.2 E+00$ & $2.4 \mathrm{E}-07$ \\
\hline S 35 & $3.31 E+01$ & & $1.7 E-04$ & $9.9 \varepsilon-03$ & $6.6 \mathrm{E}-01$ & $5.0 \mathrm{E}-08$ \\
\hline P 33 & $4.05 E-01$ & & 2.0E-05 & 1. $2 \varepsilon-04$ & $8.1 \mathrm{E}-03$ & $6.1 \mathrm{E}-10$ \\
\hline P 33 & $2.00 E+02$ & LIV & 1. $0 \mathrm{E}-03$ & $6.0 E-02$ & $4.0 E+00$ & $3.0 \mathrm{E}-07$ \\
\hline P 32 & 5. $19 \mathrm{E}+00$ & & 2. $6 \mathrm{E}-05$ & $1.6 \varepsilon-03$ & 1. $0 \mathrm{E}-01$ & 7. $8 \mathrm{E}-09$ \\
\hline S 35 & $2.29 \mathrm{E}+01$ & & $1.1 \mathrm{E}-04$ & $6.9 \varepsilon-03$ & 4. $6 \mathrm{E}-01$ & $3.4 \mathrm{E}-08$ \\
\hline $\operatorname{SC} 47^{\circ}$ & $3.98 \mathrm{E}+01$ & 83 & $2.0 E-04$ & $1.2 \varepsilon-02$ & 8.0E-01 & 6.0E-08 \\
\hline SC 46 & $1.46 \mathrm{E}-02$ & & 7. $3 E-08$ & $4.4 E-06$ & $2.9 \mathrm{E}-04$ & $2.2 \mathrm{E}-11$ \\
\hline SC $48^{b}$ & $5.59 E-02$ & & $2.8 \mathrm{E}-07$ & $1.7 \varepsilon-05$ & 1.1E-03 & $8.4 \mathrm{E}-11$ \\
\hline $\mathrm{CA} 47^{\mathrm{b}}$ & $2.33 \mathrm{E}-05$ & & 1. $2 \mathrm{E}-10$ & $7.0 \varepsilon-09$ & 4.7E-07 & $3.5 \mathrm{E}-14$ \\
\hline CU 64 & $2.18 E+01$ & R3 & $1.1 E-04$ & $6.5 E-03$ & 4.4E-01 & 3. 3E- 08 \\
\hline $\mathrm{CU} 67^{\mathrm{b}}$ & $2.11 E-03$ & & $1.1 \mathrm{E}-08$ & $6.3 \mathrm{E}-07$ & 4.2E-05 & $3.2 \mathrm{E}-12$ \\
\hline ZN 65 & $2.47 E+00$ & & $1.2 \mathrm{E}-05$ & 7.4E-04 & 4.9E-02 & $3.7 \mathrm{E}-09$ \\
\hline $\mathrm{CU} 67^{\circ}$ & $8.33 E+00$ & 83 & $4.2 E-05$ & $2.5 E-03$ & 1.7E-01 & 1. $3 E-08$ \\
\hline$Z N 65$ & $1.18 \mathrm{E}-03$ & & $5.9 E-09$ & $3.5 \mathrm{E}-07$ & $2.4 \mathrm{E}-05$ & $1.8 \mathrm{E}-12$ \\
\hline ZN 69 & $3.64 E+00$ & & $1.8 E=05$ & 1.1E-03 & 7.3E-02 & $5.5 E-09$ \\
\hline $2 N 69$ & 1. $35 E+01$ & & $6.8 E-05$ & 4.1E-03 & 2.7E-01 & $2.0 E-08$ \\
\hline SE 75 & $9.89 E+01$ & LIV & $4.9 E-04$ & $3.0 \mathrm{E}-02$ & $2.0 E+00$ & $1.5 \mathrm{E}-07$ \\
\hline AS 76 & $4.66 \mathrm{E}-02$ & & 2.3E-07 & 1.4E-05 & $9.3 \mathrm{E}-04$ & $7.0 \mathrm{E}-11$ \\
\hline AS $77^{\circ}$ & $3.95 \mathrm{E}-05$ & & $2.0 E-10$ & 1. $2 \mathrm{E}-08$ & $7.9 \varepsilon-07$ & $5.9 E-14$ \\
\hline SR 85 & $4.95 E+02$ & LIV & $2.5 E-03$ & 1. $5 E-01$ & $9.9 \varepsilon+00$ & $7.4 \mathrm{E}-07$ \\
\hline SR 89 & $6.49 E-02$ & & $3.2 E-07$ & 1. $9 \mathrm{E}-05$ & 1. $3 E-03$ & $9.7 \varepsilon-11$ \\
\hline SR 90 & $5.39 \mathrm{E}-06$ & & $2.7 €-11$ & 1. $6 \mathrm{E}-09$ & 1.1E-07 & $8.1 E-15$ \\
\hline$R B 84^{\circ}$ & 1. $30 \mathrm{E}+00$ & & $6.5 E-06$ & $3.9 E-04$ & $2: 6 \mathrm{E}-02$ & $1.9 \mathrm{E}-09$ \\
\hline RB 86 & $3.05 E+00$ & & $1.5 E-0.5$ & $9.1 \mathrm{E}-04$ & $6.1 \mathrm{E}-02$ & 4. $6 \mathrm{E}-09$ \\
\hline$K R 85$ & $4.23 E-05$ & & $4.2 E-05$ & $4.2 E-05$ & 4. $2 \mathrm{E}-05$ & $6.3 E-14$ \\
\hline
\end{tabular}


HNF-1843, Rev. O

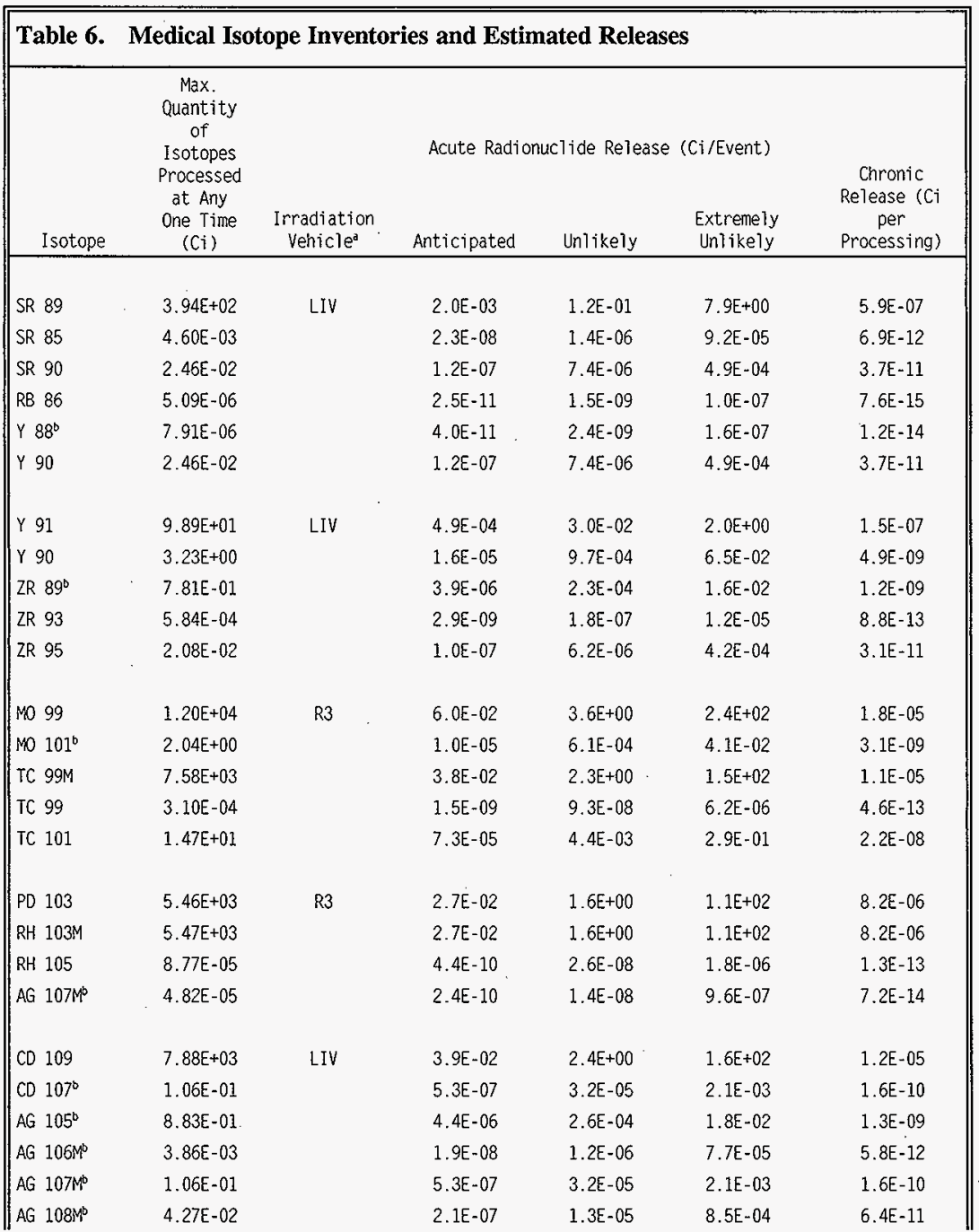


HNF-1843, Rev. 0

\section{Table 6. Medical Isotope Inventories and Estimated Releases}

\begin{tabular}{|c|c|c|c|c|c|c|}
\hline Isotope & $\begin{array}{l}\text { Max. } \\
\text { Quantity } \\
\text { of } \\
\text { Isotopes } \\
\text { Processed } \\
\text { at Any } \\
\text { One Tima } \\
\text { (Ci) }\end{array}$ & $\begin{array}{l}\text { Irradiation } \\
\text { Vehicle }\end{array}$ & Anticipated & clide Rele & $\begin{array}{l}\text { Extremely } \\
\text { Unlikely }\end{array}$ & $\begin{array}{c}\text { Chronic } \\
\text { Release (Ci } \\
\text { per } \\
\text { Processing) }\end{array}$ \\
\hline$A G 108^{b}$ & $3.84 E-03$ & & $1.9 \mathrm{E}-08$ & $1.2 \mathrm{E}-06$ & 7.7E-05 & $5.8 \mathrm{E}-12$ \\
\hline$A G 110 M$ & $4.79 E+01$ & & 2. $4 \mathrm{E}-04$ & 1. $4 \mathrm{E}-02$ & $9.6 \mathrm{E}-01$ & 7.2E-08 \\
\hline AG 110 & $6.70 E-01$ & & $3.4 \mathrm{E}-05$ & 2.0E-04 & 1. $3 \mathrm{E}-02$ & 1. $0 \mathrm{E}-09$ \\
\hline AG 111 & 7. $73 \mathrm{E}-06$ & & $3.9 \mathrm{E}-11$ & 2.3E-09 & 1.5E-07 & 1. $2 \mathrm{E}-14$ \\
\hline PD 109 & $1.64 E-03$ & & $8.2 E-09$ & 4.9E- 07 & 3. $3 E-05$ & $2.5 E-12$ \\
\hline SN 117M & $2.01 E+02$ & R3 & $1.0 E-03$ & $6.0 E-02$ & $4.0 E+00$ & $3.0 E-07$ \\
\hline SN $119 M$ & $1.68 \mathrm{E}-02$ & & 8.4E-08 & $5.0 E-06$ & $3.4 \mathrm{E}-04$ & $2.5 \mathrm{E}-11$ \\
\hline$X E 127^{\circ}$. & $2.04 E+02$ & LIV & $2.0 E+02$ & 2. $0 E+02$ & $2.0 \mathrm{E}+02$ & $3.1 \mathrm{E}-07$ \\
\hline I 125 & $8.23 E+02$ & GAS & $8.2 E+02$ & 2.5E-01 & $8.2 E+02$ & 1.2E-06 \\
\hline I $124^{\circ}$ & $3.45 E-02$ & & $3.5 E-02$ & $1.0 E-05$ & $3.5 E-02$ & $5.2 E-11$ \\
\hline I $126^{\circ}$ & $1.38 \mathrm{E}+01$ & & $1.4 \mathrm{E}+01$ & 4. $2 E-03$ & $1.4 \mathrm{E}+01$ & 2.1E-08 \\
\hline XE 125 & $8.14 E+02$ & & $8.1 \mathrm{E}+02$ & $8.1 E+02$ & $8.1 E+02$ & $1.2 \mathrm{E}-06$ \\
\hline I 131 & $6.02 E+02$ & $\mathrm{R} 3$ & 6. $0 E+02$ & $1.8 E-01$ & $6.0 E+02$ & $9.0 E-07$ \\
\hline I 129 & $1.08 \mathrm{E}-06$ & & 1.1E-06 & $3.2 \mathrm{E}-10$ & 1.1E-06 & $1.6 \mathrm{E}-15$ \\
\hline 1130 & $2.17 E+00$ & & $2.2 E+00$ & $6.5 E-04$ & 2. $2 \mathrm{E}+00$ & 3. $3 E-09$ \\
\hline TE 129M & $1.06 \mathrm{E}+01$ & & $5.3 \mathrm{E}-05$ & $3.2 E-03$ & 2.1E-01 & 1. $6 \mathrm{E}-08$ \\
\hline TE 129 & $8.76 E+01$ & & $4.4 E-04$ & $2.6 \varepsilon-02$ & $1.8 E+00$ & 1. $3 E-07$ \\
\hline TE 131 & $6.65 E+02$ & & 3. $3 E-03$ & $2.0 E=01$ & $1.3 E+01$ & $1.0 E-06$ \\
\hline SM $145^{\circ}$ & $1.01 E+02$ & LIV & 5.1E-04 & $3.0 E-02$ & $2.0 \mathrm{E}+00$ & $1.5 E-07$ \\
\hline SM $146^{b}$ & $5.53 \mathrm{E}-07$ & & $2.8 \mathrm{E}-12$ & 1. $7 E-10$ & 1.1E-08 & 8.3E-16 \\
\hline SM 151 & $1.74 \mathrm{E}-01$ & & $8.7 E-07$ & $5.2 E-05$ & $3.5 E-03$ & $2.6 E-10$ \\
\hline PM $145^{\circ}$ & $2.06 E+00$ & & $1.0 E-05$ & $6.2 E-04$ & 4.1E-02 & $3.1 \mathrm{E}-09$ \\
\hline$P M 146^{\circ}$ & $1.23 E-01$ & & $6.2 E-07$ & $3.7 \mathrm{E}-05$ & $2.5 \mathrm{E}-03$ & 1. $9 E-10$ \\
\hline PM 147 & $2.76 \mathrm{E}-03$ & & $1.4 \mathrm{E}-08$ & $8.3 \mathrm{E}-07$ & $5.5 E-05$ & $4.1 E-12$ \\
\hline PM 148M & $1.85 E-03$ & & $9.3 E-09$ & $5.6 \mathrm{E}-07$ & $3.7 \mathrm{E}-05$ & $2.8 E-12$ \\
\hline PM 148 & $4.21 \mathrm{E}-03$ & & $2.1 E-08$ & 1.3E-06 & $8.4 \mathrm{E}-05$ & $6.3 \mathrm{E}-12$ \\
\hline
\end{tabular}




\begin{tabular}{|c|c|c|c|c|c|c|}
\hline \multicolumn{7}{|c|}{ Table 6. Medical Isotope Inventories and Estimated Releases } \\
\hline Isotope & $\begin{array}{l}\text { Max. } \\
\text { Quantity } \\
\text { of } \\
\text { Isotopes } \\
\text { Processed } \\
\text { at Any } \\
\text { One Time } \\
\text { (Ci) }\end{array}$ & \multicolumn{5}{|c|}{ Acute Radionuclide Release (Ci/Event) } \\
\hline PM 149 & $1.49 E-03$ & & $7.4 \mathrm{E}-09$ & $4.5 E-07$ & $3.0 \mathrm{E}-05$ & $2.2 \varepsilon-12$ \\
\hline ND 147 & $4.57 E-04$ & & $2.3 E-09$ & $1.4 \mathrm{E}-07$ & $9.1 \mathrm{E}-06$ & $6.8 \varepsilon-13$ \\
\hline SM 153 & $7.98 E+01$ & $\mathrm{R} 3$ & $4.0 E-04$ & $2.4 \mathrm{E}-02$ & $1.6 \mathrm{E}+00$ & $1.2 E-07$ \\
\hline SM 151 & $2.02 E-06$ & & $1.0 \mathrm{E}-11$ & $6.1 E-10$ & 4.0E-08 & $3.0 \mathrm{E}-15$ \\
\hline SM $155^{\circ}$ & $4.06 E-04$ & & $2.0 \mathrm{E}-09$ & $1.2 \mathrm{E}-07$ & 8.1E-06 & $6.1 \mathrm{E}-13$ \\
\hline SM $156^{\circ}$ & $1.22 E-07$ & & $6.1 \mathrm{E}-13$ & $3.7 €-11$ & $2.4 \mathrm{E}-09$ & 1. $8 \mathrm{E}-16$ \\
\hline EU 152M & $5.03 E-08$ & & $2.5 E-13$ & $1.5 \varepsilon-11$ & 1.0E-09 & $7.5 E-17$ \\
\hline EU 154M & $1.97 \varepsilon-01$ & & $9.8 \mathrm{E}-07$ & $5.9 E-05$ & $3.9 E-03$ & $2.9 \mathrm{E}-10$ \\
\hline EU 154 & $3.02 E-03$ & & $1.5 E-08$ & $9.0 \varepsilon-07$ & $6.0 E-05$ & $4.5 \mathrm{E}-12$ \\
\hline EU 155 & 3. $13 E-04$ & & $1.6 \mathrm{E}-09$ & $9.4 E-08$ & $6.3 \mathrm{E}-06$ & 4.7E-13 \\
\hline EU 156 & $8.56 \varepsilon-03$ & & 4.3E-08 & $2.6 E-06$ & 1.7E-04 & 1.3E-11 \\
\hline GD 153 & $6.15 E+03$ & LIV & 3. $1 \mathrm{E}-02$ & $1.8 E+00$ & 1.2E+02 & 9.2E-06 \\
\hline SM 153 & $6.37 E-05$ & & $3.2 \mathrm{E}-10$ & 1. $9 \mathrm{E}-08$ & $1.3 \mathrm{E}-06$ & $9.6 \mathrm{E}-14$ \\
\hline EU 152M & $2.27 \varepsilon-05$ & & 1. $1 \mathrm{E}-10$ & $6.8 \mathrm{E}-09$ & $4.5 \mathrm{E}-07$ & $3.4 E-14$ \\
\hline EU 152 & $3.33 E+03$ & & 1.7E-02 & 1. $0 E+00$ & $6.7 \mathrm{E}+01$ & 5.0E-06 \\
\hline EU $154 M^{b}$ & $3.14 E-05$ & & $1.6 \mathrm{E}-10$ & $9.4 E-09$ & $6.3 \mathrm{E}-07$ & $4.7 €-14$ \\
\hline EU 154 & $1.75 E+04$ & & $8.8 E-02$ & $5.3 E+00$ & $3.5 E+02$ & $2.6 \mathrm{E}-05$ \\
\hline EU 155 & $6.14 E+03$ & & $3.1 E-02$ & $1.8 \mathrm{E}+00$ & $1.2 E+02$ & $9.2 \varepsilon-06$ \\
\hline EU 156 & $8.26 E+04$ & & $4.1 E-01$ & $2.5 E+01$ & 1.7E+03 & $1.2 E-04$ \\
\hline HO 166 & $3.98 E+01$ & R3 & $2.0 E-04$ & $1.2 \mathrm{E}-02$ & $8.0 \mathrm{E}-01$ & $6.0 E-08$ \\
\hline HO $166 \mathrm{M}$ & $3.84 E-05$ & & $1.9 E-10$ & 1.2E-08 & 7.7E-07 & $5.8 E-14$ \\
\hline HO $167^{\circ}$ & $9.66 \mathrm{E}-03$ & & $4.8 \mathrm{E}-08$ & $2.9 E-06$ & $1.9 E-04$ & $1.4 E-11$ \\
\hline ER $167^{\circ}$ & $9.66 \mathrm{E}-03$ & & $4.8 \varepsilon-08$ & $2.9 E-05$ & $1.9 E-04$ & $1.4 \mathrm{E}-11$ \\
\hline OY $166^{\circ}$ & $9.64 E-07$ & & $4.8 E-12$ & $2.9 E-10$ & $1.9 E-08$ & $1.4 E-15$ \\
\hline LU $177^{\circ}$ & $9.82 E+00$ & R3 & $4.9 E-05$ & $2.9 \mathrm{E}-03$ & $2.0 \mathrm{E}-01$ & $1.5 \mathrm{E}-08$ \\
\hline LU $176 M^{\circ}$ & 1. $10 \mathrm{E}+00$ & $5.5 E-06$ & $3.3 E-04$ & $2.2 \mathrm{E}-02$ & \multicolumn{2}{|c|}{$1.7 \mathrm{E}-09$} \\
\hline LU $177 M^{\circ}$ & $1.08 E-03$ & & $5.4 E-09$ & $3.2 E-07$ & $2.2 \mathrm{E}-05$ & $1.6 \mathrm{E}-12$ \\
\hline LU $178^{\circ}$ & $3.24 \mathrm{E}-04$ & & $1.6 \mathrm{E}-09$ & $9.7 E-08$ & $6.5 E-06$ & $4.9 E-13$ \\
\hline
\end{tabular}


HNF-1843, Rev. 0

\begin{tabular}{|c|c|c|c|c|c|c|}
\hline \multirow[b]{2}{*}{ Isotope } & \multirow{2}{*}{$\begin{array}{c}\text { Max. } \\
\text { Quantity } \\
\text { of } \\
\text { Isotopes } \\
\text { Processed } \\
\text { at Any } \\
\text { One Time } \\
\text { (Ci) }\end{array}$} & \multicolumn{5}{|c|}{ Acute Radionuclide Release (Ci/Event) } \\
\hline & & $\begin{array}{c}\text { Irradiation } \\
\text { Vehicle }^{\mathrm{j}}\end{array}$ & Anticipated & Unilkely & $\begin{array}{l}\text { Extremely } \\
\text { Unitikely }\end{array}$ & $\begin{array}{c}\text { per } \\
\text { Processing) }\end{array}$ \\
\hline LU $179^{\circ}$ & $5.52 E-08$ & & $2.8 \varepsilon-13$ & $1.7 E-11$ & 1.1E-09 & $8.3 \mathrm{E}-17$ \\
\hline HF $177 \mathrm{MP}^{\circ}$ & $1.42 E-03$ & & $7.1 E-09$ & $4.3 E-07$ & $2.8 \mathrm{E}-05$ & 2.1E-12 \\
\hline HF $178 \mathrm{~N}^{\mathrm{p}}$ & $1.90 E-05$ & & $9.5 E-11$ & $5.7 \varepsilon-09$ & $3.8 \mathrm{E}-07$ & $2.9 E-14$ \\
\hline HF $179 \mathrm{NP}^{\mathrm{s}}$ & $1.51 \mathrm{E}-05$ & & $7.6 E-11$ & 4.5E-09 & $3.0 \mathrm{E}-07$ & 2.3E-14 \\
\hline W $188^{\circ}$ & $3.28 E+04$ & LIV & $1.6 \mathrm{E}-01$ & $9.8 \mathrm{E}+00$ & $6.6 \mathrm{E}+02$ & $4.9 \varepsilon-05$ \\
\hline W 181 & $2.82 E-03$ & & 1. $4 \mathrm{E}-08$ & $8.4 \mathrm{E}-07$ & $5.6 \mathrm{E}-05$ & $4.2 \mathrm{E}-12$ \\
\hline W 185 & $9.23 E+04$ & & 4. $6 \mathrm{E}-01$ & $2.8 \mathrm{E}+01$ & $1.8 \mathrm{E}+03$ & 1. $4 E-04$ \\
\hline W 187 & $1.77 \varepsilon+05$ & & $8.8 \mathrm{E}-01$ & $5.3 \mathrm{E}+01$ & $3.5 E+03$ & $2.6 E-04$ \\
\hline TA 182 & $1.20 E-05$ & & $6.0 \mathrm{E}-11$ & $3.6 \mathrm{E}-09$ & $2.4 \mathrm{E}-07$ & $1.8 \mathrm{E}-14$ \\
\hline TA $183^{\circ}$ & $8.04 E-05$ & & $4.0 \mathrm{E}-10$ & $2.4 \mathrm{E}-08$ & $1.6 \mathrm{E}-06$ & $1.2 \mathrm{E}-13$ \\
\hline RE $186 \mathrm{M}^{\circ}$ & $4.64 E-03$ & & $2.3 \mathrm{E}-08$ & $1.4 E-06$ & $9.3 E-05$ & $7.0 \mathrm{E}-12$ \\
\hline $\operatorname{RE} 186^{\circ}$ & $4.80 E+03$ & & $2.4 \mathrm{E}-02$ & $1.4 \mathrm{E}+00$ & $9.6 \mathrm{E}+01$ & 7.2E-06 \\
\hline RE $188 M^{\circ}$ & $1.54 E-06$ & & $8.2 \mathrm{E}-12$ & $4.9 \mathrm{E}-10$ & $3.3 \mathrm{E}-08$ & $2.5 E-15$ \\
\hline RE $188^{\circ}$ & $3.98 E+04$ & & 2. $0 \mathrm{E}-01$ & $1.2 \mathrm{E}+01$ & $8.0 \mathrm{E}+02$ & $6.0 E-05$ \\
\hline RE $189^{\circ}$ & $2.68 E+01$ & & 1.3E-04 & 8.0E-03 & $5.4 \mathrm{E}-01$ & 4. $0 E-08$ \\
\hline $\begin{array}{l}\text { OS 189MD } \\
3.53 \mathrm{E}+01\end{array}$ & $1.8 E-04$ & & $1.1 \mathrm{E}-02$ & 7.1E-01 & 5. $3 \mathrm{E}-08$ & \\
\hline RE $186^{\mathrm{b}}$ & $6.98 \mathrm{E}+03$ & R3 & $3.5 E-02$ & $2.1 E \div 00$ & 1. $4 \mathrm{E}+02$ & 1. $.0 E-05$ \\
\hline RE $186 \mu^{\circ}$ & $1.71 E-03$ & & $8.6 E-09$ & $5.1 \mathrm{E}-07$ & 3. $4 \mathrm{E}-05$ & $2.5 E-12$ \\
\hline RE $188^{b}$ & $4.80 E+02$ & & $2.4 E-03$ & 1. $4 \mathrm{E}-01$ & $9.6 \mathrm{E}+00$ & $7.2 E-07$ \\
\hline RE $189^{b}$ & . $9.32 E-02$ & & 4.7E-07 & 2. $8 \mathrm{E}-05$ & 1.9E-03 & 1. $4 E-10$ \\
\hline OS $189 \mu^{\phi}$ & $4.03 E+00$ & & 2.0E-05 & $1.2 \mathrm{E}-03$ & 8.1E-02 & $6.0 \mathrm{E}-09$ \\
\hline W 187 & $3.68 \mathrm{E}-01$ & & $1.8 \mathrm{E}-06$ & 1.1E-04 & $7.4 \mathrm{E}-03$ & $5.5 \mathrm{E}-10$ \\
\hline W $188^{\circ}$ & $1.16 \mathrm{E}-09$ & & $5.8 E-15$ & $3.5 \mathrm{E}-13$ & $2.3 E-11$ & 1.7E-18 \\
\hline OS $194^{b}$ & $2.64 \mathrm{E}+01$ & LIV & 1.3E-04 & $7.9 \mathrm{E}-03$ & 5.3E-01 & 4.0E-08 \\
\hline OS 191M" & $5.01 E+02$ & & $2.5 E-03$ & $1.5 \mathrm{E}-01$ & $1.0 E+01$ & $7.5 \mathrm{E}-07$ \\
\hline OS 191 & $3.28 \mathrm{E}+05$ & & 1. $6 \mathrm{E}+00$ & $9.8 \mathrm{E}+01$ & $6.6 E+03$ & $4.9 E-04$ \\
\hline OS $193^{\circ}$ & $1.51 \mathrm{I}+05$ & & $7.5 E-01$ & $4.5 E+01$ & $3.0 E+03$ & 2.3E-04 \\
\hline
\end{tabular}




\begin{tabular}{|c|c|c|c|c|c|c|}
\hline \multirow[b]{2}{*}{ Isotope } & \multirow{2}{*}{$\begin{array}{c}\text { Max. } \\
\text { Quantity } \\
\text { of } \\
\text { Isotopes } \\
\text { Processed } \\
\text { at Any } \\
\text { One Time } \\
\text { (Ci) }\end{array}$} & \multirow[b]{2}{*}{$\begin{array}{c}\text { Irradiation } \\
\text { Vehicle }^{3}\end{array}$} & \multicolumn{3}{|c|}{ Acute Radionuclide Release ( $\mathrm{Ci} /$ Event) } & \multirow{2}{*}{$\begin{array}{c}\text { Chronic } \\
\text { Release (Ci } \\
\text { per } \\
\text { Processing) }\end{array}$} \\
\hline & & & Anticipated & Unlikely & $\begin{array}{l}\text { Extremely } \\
\text { Unlikely }\end{array}$ & \\
\hline IR 192 & $1.15 E+03$ & & $5.7 \mathrm{E}-03$ & $3.4 \mathrm{E}-01$ & $2.3 \mathrm{E}+01$ & $1.7 \varepsilon-06$ \\
\hline IR $193 \mathrm{M}^{\circ}$ & $1.05 E+01$ & & $5.3 E-05$ & $3.2 E-03$ & 2.1E-01 & $1.6 \varepsilon-08$ \\
\hline IR $194 \mathrm{M}^{\circ}$ & $1.47 \mathrm{E}-03$ & & $7.3 \mathrm{E}-09$ & 4. $4 \mathrm{E}-07$ & 2.9E-05 & $2.2 E-12$ \\
\hline IR $194^{D}$ & $2.64 E+01$ & & $1.3 \mathrm{E}-04$ & $7.9 \mathrm{E}-03$ & $5.3 E-01$ & 4. $0 E-08$ \\
\hline IR 192 & $2.00 E+06$ & LIV & $1.0 E+01$ & $6.0 E+02$ & $4.0 \mathrm{E}+04$ & $3.0 E-03$ \\
\hline IR $192 M^{\circ}$ & $2.75 \mathrm{E}+01$ & & $1.4 E-04$ & $8.3 E-03$ & $5.5 E-01$ & 4. $1 E-08$ \\
\hline IR $193 \mathrm{M}^{\circ}$ & $1.62 E+04$ & & $8.1 E-02$ & $4.9 E+00$ & $3.2 \mathrm{E}+02$ & $2.4 E-05$ \\
\hline IR $194 M^{D}$ & $6.84 E+03$ & & $3.4 E-02$ & $2.1 E+00$ & $1.4 \mathrm{E}+02$ & $1.0 E-05$ \\
\hline IR $194^{\circ}$ & $2.83 E+02$ & & $1.4 E-03$ & $8.5 E-02$ & $5.7 E+00$ & 4. $2 \mathrm{E}-07$ \\
\hline PT 19310 & $2.23 E+03$ & & $1.1 E-02$ & $6.7 \mathrm{E}-01$ & $4.5 E+01$ & $3.3 E-06$ \\
\hline PT $193^{b}$ & $2.80 E+01$ & & $1.4 E-04$ & $8.4 \mathrm{E}-03$ & $5.6 \varepsilon-01$ & 4. $2 E-08$ \\
\hline PT 195M & $1.45 E+02$ & & 7. $3 E-04$ & 4. $4 \mathrm{E}-02$ & $2.9 \varepsilon+00$ & $2.2 \mathrm{E}-07$ \\
\hline PT 195 & $4.46 \mathrm{E}+00$ & R3 & $2.2 E-05$ & 1. $3 E-03$ & $8.9 \mathrm{E}-02$ & $6.7 \mathrm{E}-09$ \\
\hline PT 193M & $8.78 \mathrm{E}+00$ & & 4. $4 \mathrm{E}-05$ & $2.6 \mathrm{E}-03$ & 1. $8 \mathrm{E}-01$ & 1. $3 E-08$ \\
\hline PT $193^{b}$ & 1.39E-01 & & $6.9 \varepsilon-07$ & 4. $2 E-05$ & $2.8 \mathrm{E}-03$ & 2.1E-10 \\
\hline PT $197^{\circ}$ & $8.63 E+01$ & & 4. $3 \mathrm{E}-04$ & $2.6 \mathrm{E}-02$ & $1.7 E+00$ & $1.3 \mathrm{E}-07$ \\
\hline IR $193 M^{b}$ & 1.08E-01 & & $5.4 E-07$ & 3.2E-05 & $2.2 \mathrm{E}-03$ & $1.6 E-10$ \\
\hline IR 1944 & $1.83 E-04$ & & $9.2 E-10$ & $5.5 \mathrm{E}-08$ & $3.7 \mathrm{E}-06$ & $2.7 E-13$ \\
\hline IR $194^{\circ}$ & 4.24E-05 & & $2.1 \mathrm{E}-10$ & 1.3E-08 & $8.5 E-07$ & $6.4 E-14$ \\
\hline AU 1971\% & $8.63 E+01$ & & 4. $3 E-04$ & $2.6 \mathrm{E}-02$ & 1. $7 \mathrm{E}+00$ & 1. $3 E-07$ \\
\hline AU $198^{\circ}$ & $1.81 E+02$ & R3 & $9.1 \mathrm{E}-04$ & $5.4 \mathrm{E}-02$ & $3.6 \mathrm{E}+00$ & 2.7E-07 \\
\hline AU $196^{\circ}$ & $2.14 E-02$ & & 1.1E-07 & $6.4 \mathrm{E}-06$ & $4.3 \mathrm{E}-04$ & 3.2E-11 \\
\hline AU $198 \mathrm{M}^{\circ}$ & $1.33 \mathrm{E}+02$ & & $6.6 \mathrm{E}-04$ & 4.0E-02 & $2.7 \mathrm{E}+00$ & 2. $0 E-07$ \\
\hline AU $199^{\circ}$ & $3.37 E+02$ & & 1.7E-03 & 1.0E-01 & $6.7 E+00$ & $5.1 E-07$ \\
\hline AU $200 \mathrm{M}^{\circ}$ & 1.23E-01 & & $6.2 \mathrm{E}-07$ & 3.7E-05 & $2.5 E-03$ & 1. $8 \mathrm{E}-10$ \\
\hline$A U 200^{\circ}$ & $4.14 E-02$ & & 2.1E-07 & $1.2 \mathrm{E}-05$ & $8.3 E-04$ & $6.2 \mathrm{E}-11$ \\
\hline PT $197^{\circ}$ & $1.18 E-05$ & & $5.9 E-11$ & $3.5 \mathrm{E}-09$ & $2.4 \mathrm{E}-07$ & 1. $8 \mathrm{E}-14$ \\
\hline
\end{tabular}


HNF-1843, Rev. 0

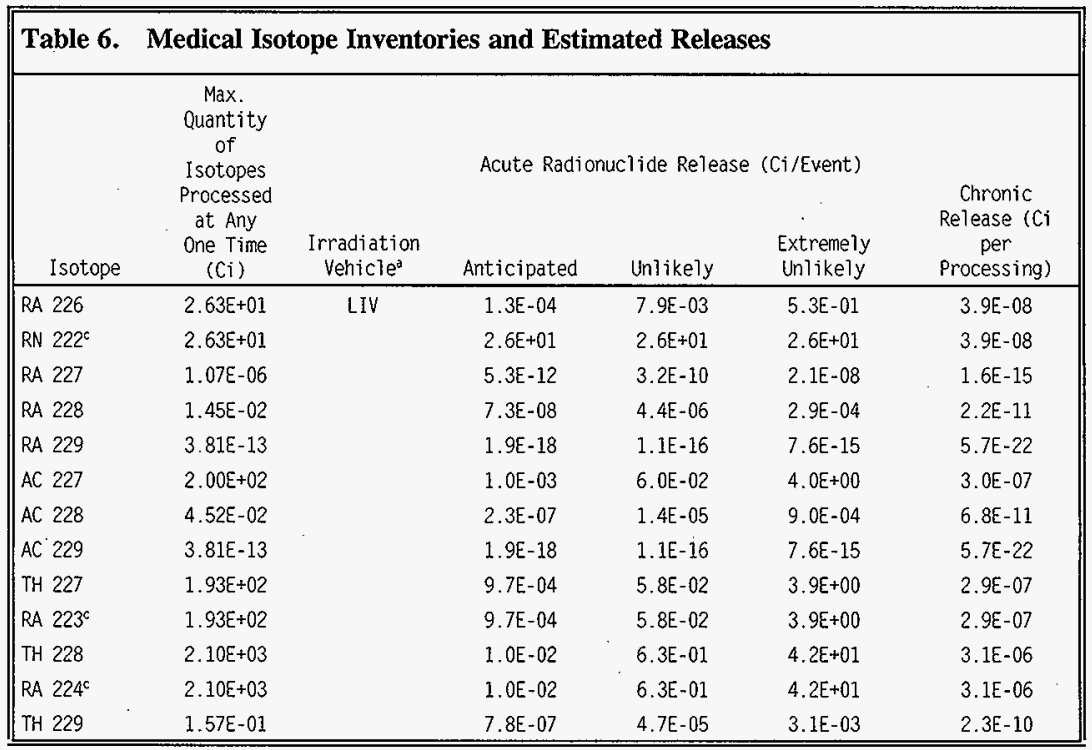

R3 = Rapid Radioisotope Retrieval System: LIV = Long Irradiation Vehicle: GAS = gas line.

- Indicates isotopes that are not in the radionuclide library, and which are not included in the calculations. Doses are not reported for medical isotope assemblies where the product isotope is not in the software radionuclide library.

c Indicates short-7ived decay products that are assumed to be in equilibrium with parent isotopes at the time of processing. 
HNF-1843, Rev. 0

\begin{tabular}{|c|c|c|c|c|c|c|c|}
\hline \multirow[b]{2}{*}{ Isotope Target } & \multirow{2}{*}{$\begin{array}{c}\text { Maximum No. } \\
\text { Targets } \\
\text { Processed } \\
\text { Annually* }\end{array}$} & \multicolumn{2}{|c|}{$\begin{array}{c}\text { Onsite Worker } \\
300 \mathrm{~m} \mathrm{NE} \\
\text { Dose to Individual } \\
\text { (rem) }\end{array}$} & \multicolumn{2}{|c|}{$\begin{array}{c}\text { Offsite Resident } \\
1500 \mathrm{~m} \text { NE } \\
\text { Dose to Individual } \\
\text { (rem) }\end{array}$} & \multicolumn{2}{|c|}{$\begin{array}{c}\text { Population } \\
0-50 \mathrm{mi} \text { from } 300 \text { Area } \\
\text { Collective Dose to Population } \\
\text { (person-rem) }\end{array}$} \\
\hline & & Per Target & Annual * & Per Target & Annual * & Per Target & Annual * \\
\hline $\begin{array}{c}\text { AC-227 } \\
\text { Cd-109 } \\
\text { Cu-64 } \\
\text { Gd-153 } \\
\text { Ho-166 } \\
\text { I- } 125 \\
\text { I-131 } \\
\text { Ir-192 } \\
\text { Mo-99 } \\
\text { P-32 } \\
\text { P-33 } \\
\text { Pd-103 } \\
\text { Se-75 } \\
\text { Sm-153 } \\
\text { Sn-117m } \\
\text { Sr-85 } \\
\text { Sr-89 } \\
\text { Th-228 } \\
\text { Th-229 } \\
\text { W- } 188 \\
\text { Y-91 }\end{array}$ & $\begin{array}{c}2 \\
1 \\
50 \\
1 \\
50 \\
17 \\
20 \\
1 \\
50 \\
10 \\
3 \\
10 \\
2 \\
50 \\
10 \\
2 \\
3 \\
2 \\
2 \\
2 \\
2 \\
\end{array}$ & $\begin{array}{l}1.9 \mathrm{E}-08 \\
1.9 \mathrm{E}-11 \\
7.6 \mathrm{E}-15 \\
3.7 \mathrm{E}-10 \\
2.7 \mathrm{E}-15 \\
6.9 \mathrm{E}-13 \\
1.0 \mathrm{E}-12 \\
5.0 \mathrm{E}-09 \\
8.6 \mathrm{E}-13 \\
2.1 \mathrm{E}-14 \\
4.2 \mathrm{E}-15 \\
2.1 \mathrm{E}-13 \\
1.6 \mathrm{E}-13 \\
3.7 \mathrm{E}-15 \\
3.3 \mathrm{E}-14 \\
5.4 \mathrm{E}-13 \\
4.4 \mathrm{E}-14 \\
1.9 \mathrm{E}-08 \\
1.9 \mathrm{E}-08 \\
7.8 \mathrm{E}-12 \\
9.9 \mathrm{E}-14\end{array}$ & $\begin{array}{l}3.8 \mathrm{E}-08 \\
1.9 \mathrm{E}-11 \\
3.8 \mathrm{E}-13 \\
3.7 \mathrm{E}-10 \\
1.4 \mathrm{E}-13 \\
1.2 \mathrm{E}-11 \\
2.0 \mathrm{E}-11 \\
5.0 \mathrm{E}-09 \\
4.3 \mathrm{E}-11 \\
2.1 \mathrm{E}-13 \\
1.1 \mathrm{E}-14 \\
2.1 \mathrm{E}-12 \\
3.2 \mathrm{E}-13 \\
1.8 \mathrm{E}-13 \\
3.3 \mathrm{E}-13 \\
1.1 \mathrm{E}-12 \\
1.1 \mathrm{E}-13 \\
3.8 \mathrm{E}-08 \\
3.8 \mathrm{E}-08 \\
1.6 \mathrm{E}-11 \\
2.0 \mathrm{E}-13\end{array}$ & $\begin{array}{l}3.5 \mathrm{E}-08 \\
6.7 \mathrm{E}-11 \\
5.9 \mathrm{E}-14 \\
7.8 \mathrm{E}-10 \\
5.3 \mathrm{E}-15 \\
1.2 \mathrm{E}-10 \\
5.2 \mathrm{E}-11 \\
1.1 \mathrm{E}-08 \\
2.2 \mathrm{E}-12 \\
5.0 \mathrm{E}-13 \\
1.1 \mathrm{E}-13 \\
1.1 \mathrm{E}-12 \\
6.0 \mathrm{E}-12 \\
8.0 \mathrm{E}-15 \\
1.1 \mathrm{E}-13 \\
1.1 \mathrm{E}-12 \\
7.4 \mathrm{E}-13 \\
3.5 \mathrm{E}-08 \\
3.5 \mathrm{E}-08 \\
6.7 \mathrm{E}-11 \\
3.1 \mathrm{E}-13\end{array}$ & $\begin{array}{l}7.0 \mathrm{E}-08 \\
6.7 \mathrm{E}-11 \\
3.0 \mathrm{E}-12 \\
7.8 \mathrm{E}-10 \\
2.6 \mathrm{E}-13 \\
2.0 \mathrm{E}-09 \\
1.0 \mathrm{E}-09 \\
1.1 \mathrm{E}-08 \\
1.1 \mathrm{E}-10 \\
5.0 \mathrm{E}-12 \\
2.8 \mathrm{E}-13 \\
1.1 \mathrm{E}-11 \\
1.2 \mathrm{E}-11 \\
4.0 \mathrm{E}-13 \\
1.1 \mathrm{E}-12 \\
2.2 \mathrm{E}-12 \\
1.8 \mathrm{E}-12 \\
7.0 \mathrm{E}-08 \\
7.0 \mathrm{E}-08 \\
1.3 \mathrm{E}-10 \\
6.2 \mathrm{E}-13 \\
\end{array}$ & $\begin{array}{c}5.3 E-04 \\
7.6 \mathrm{E}-07 \\
6.3 \mathrm{E}-10 \\
6.7 \mathrm{E}-06 \\
7.0 \mathrm{E}-11 \\
1.2 \mathrm{E}-06 \\
4.2 \mathrm{E}-07 \\
7.9 \mathrm{E}-05 \\
1.9 \mathrm{E}-08 \\
4.9 \mathrm{E}-09 \\
1.2 \mathrm{E}-09 \\
1.1 \mathrm{E}-08 \\
7.2 \mathrm{E}-08 \\
9.1 \mathrm{E}-11 \\
9.0 \mathrm{E}-10 \\
6.6 \mathrm{E}-09 \\
5.9 \mathrm{E}-09 \\
5.3 \mathrm{E}-04 \\
5.3 \mathrm{E}-04 \\
6.1 \mathrm{E}-07 \\
3.5 \mathrm{E}-09 \\
\end{array}$ & $\begin{array}{l}1.1 \mathrm{E}-03 \\
7.6 \mathrm{E}-07 \\
3.2 \mathrm{E}-08 \\
6.7 \mathrm{E}-06 \\
3.5 \mathrm{E}-09 \\
2.0 \mathrm{E}-05 \\
8.4 \mathrm{E}-06 \\
7.9 \mathrm{E}-05 \\
9.5 \mathrm{E}-07 \\
4.9 \mathrm{E}-08 \\
3.0 \mathrm{E}-09 \\
1.1 \mathrm{E}-07 \\
1.4 \mathrm{E}-07 \\
4.6 \mathrm{E}-09 \\
9.0 \mathrm{E}-09 \\
1.3 \mathrm{E}-08 \\
1.5 \mathrm{E}-08 \\
1.1 \mathrm{E}-03 \\
1.1 \mathrm{E}-03 \\
1.2 \mathrm{E}-06 \\
7.0 \mathrm{E}-09\end{array}$ \\
\hline
\end{tabular}

* Annual Doses are based on processing up to 3 long irradiation vehicle (LIV) assemblies or up to 50 rapid radioisotope retrieval (R3) assemblies per year. I-125 is collected from a continuous gas loop in a collection device, which is assumed to be processed a maximum of 17 times per year. 
HNF-1843, Rev. 0

Table 8. Consequences of Potential Accidents During Medical Isotope Target Processing at Hanford 325 Bui 7 ding

(Sheet 1) Consequences to Onsite Worker and Individual at Nearest Public Access Location

Anticipated Accident - Localized Fire

Event Frequency $=<1 \mathrm{E}-1 /$ year

Frequency of atmospheric conditions $=<0.5 \%$

Relative frequency of atmospheric conditions (compared to anticipated conditions at $50 \%$ frequency) $=<0.01$

\begin{tabular}{|c|c|c|c|c|}
\hline \multirow{2}{*}{$\begin{array}{c}\text { Receptor/ } \\
\text { Location } \\
\text { Isotope Target (by primary } \\
\left.\text { product except } \mathrm{Ra}_{a}-226^{*}\right)\end{array}$} & \multicolumn{2}{|c|}{$\begin{array}{l}\text { Onsite Worker } \\
100 \mathrm{~m} \text { NE of } 325 \text { Building }\end{array}$} & \multicolumn{2}{|c|}{$\begin{array}{l}\text { Nearest Public Access } \\
470 \mathrm{~m} \text { WNW of } 325 \text { Building }\end{array}$} \\
\hline & $\begin{array}{l}\text { Dose to } \\
\text { Individual } \\
\text { (rem) }{ }^{\star \star} \mathrm{LCF}^{\star \star \star}\end{array}$ & $\begin{array}{l}\text { Individual Risk } \\
\text { of an LCF }\end{array}$ & $\begin{array}{c}\text { Dose to } \\
\text { Individual } \\
(\text { rem }) \star \star 1 C F * \star *\end{array}$ & $\begin{array}{l}\text { Individual Risk } \\
\text { of an LCF }\end{array}$ \\
\hline $\begin{array}{c}\text { Cd-109 } \\
\text { Cu-64 } \\
\text { Gd-153 } \\
\text { Ho-166 } \\
I-125 \\
\text { I-131 } \\
\text { Ir-192 } \\
\text { Mo-99 } \\
\rho-32 \\
\text { P-33 } \\
\text { Pd-103 } \\
\text { Ra-226 } \\
\text { Se-75 } \\
\text { Sm-153 } \\
\text { Sn-117m } \\
\text { Sr-85 } \\
\text { Sr-89 } \\
\text { Y-91 }\end{array}$ & $\begin{array}{l}2.0 E-038 . E-07 \\
1.1 E-074 \cdot E-11 \\
3.0 E-021 . E-5 \\
3.0 E-071 \cdot E-10 \\
2.1 E+008 \cdot E-04 \\
2.0 E+008 \cdot E-04 \\
2.5 E-011 . E-04 \\
5.5 E-052 . E-08 \\
2.3 E-069 . E-10 \\
4.5 E-072 . E-10 \\
1.9 E-058 . E-09 \\
1.1 E+005 . E-04 \\
1.8 E-067 . E-10 \\
3.5 E-071 \cdot E-10 \\
1.9 E-068 \cdot E-10 \\
2.0 E-068 \cdot E-13 \\
4.8 E-062 . E-09 \\
7.5 E-063 \cdot E-09\end{array}$ & $\begin{array}{l}\text { 8.E-10 } \\
4 . E-14 \\
1 . E-08 \\
1 . E-13 \\
8 . E-07 \\
8 . E-07 \\
1 . E-07 \\
2 . E-11 \\
9 . E-13 \\
2 . E-13 \\
8 . E-12 \\
5 . E-07 \\
7 . E-13 \\
1 . E-13 \\
8 . E-13 \\
8 . E-13 \\
2 . E-12 \\
\text { 3.E-12 }\end{array}$ & $\begin{array}{l}2.3 E-041 . E-07 \\
1.4 E-087 . E-12 \\
1.8 E-039 . E-07 \\
3.5 E-082 . E-11 \\
2.4 E-011 . E-04 \\
2.4 E-011 . E-04 \\
2.9 E-021 . E-05 \\
7.0 E-064 . E-09 \\
2.8 E-071 . E-10 \\
5.5 E-083 . E-11 \\
2.3 E-061 . E-09 \\
1.2 E-016 . E-05 \\
2.1 E-071 . E-10 \\
4.3 E-082 . E-11 \\
2.3 E-071 . E-10 \\
2.5 E-071 . E-10 \\
5.5 E-073 . E-10 \\
9.8 E-075 . E-10\end{array}$ & $\begin{array}{l}1 . E-10 \\
\text { 7.E-15 } \\
9 . E-10 \\
2 . E-14 \\
1 . E-07 \\
1 . E-07 \\
1 . E-08 \\
4 . E-12 \\
1 . E-13 \\
3 . E-14 \\
1 . E-12 \\
6 . E-08 \\
1 . E-13 \\
2 . E-14 \\
1 . E-13 \\
1 . E-13 \\
3 . E-13 \\
\text { 5.E-13 }\end{array}$ \\
\hline
\end{tabular}

* Doses include primary product and selected impurities (some impurities were not included because they were not in the radionuclide 1 ibrary). Ra-226 target includes target material, selected impurities, and products Ac-227. Th-228, and Th-229. The target is processed in four separate runs to reduce the amount of material that can be released in an accident.

** Calculated doses are for the inhalation, air submersion, and ground surface external dose pathways. They assume exposure to the entire plume and include no protective action other than evacuation after the plume passage.

$* * *$ LCF assuming the accident occurred. i.e. not taking credit for the probability of the accident or for the frequency of the atmospheric conditions. 
HNF-1843, Rev. 0

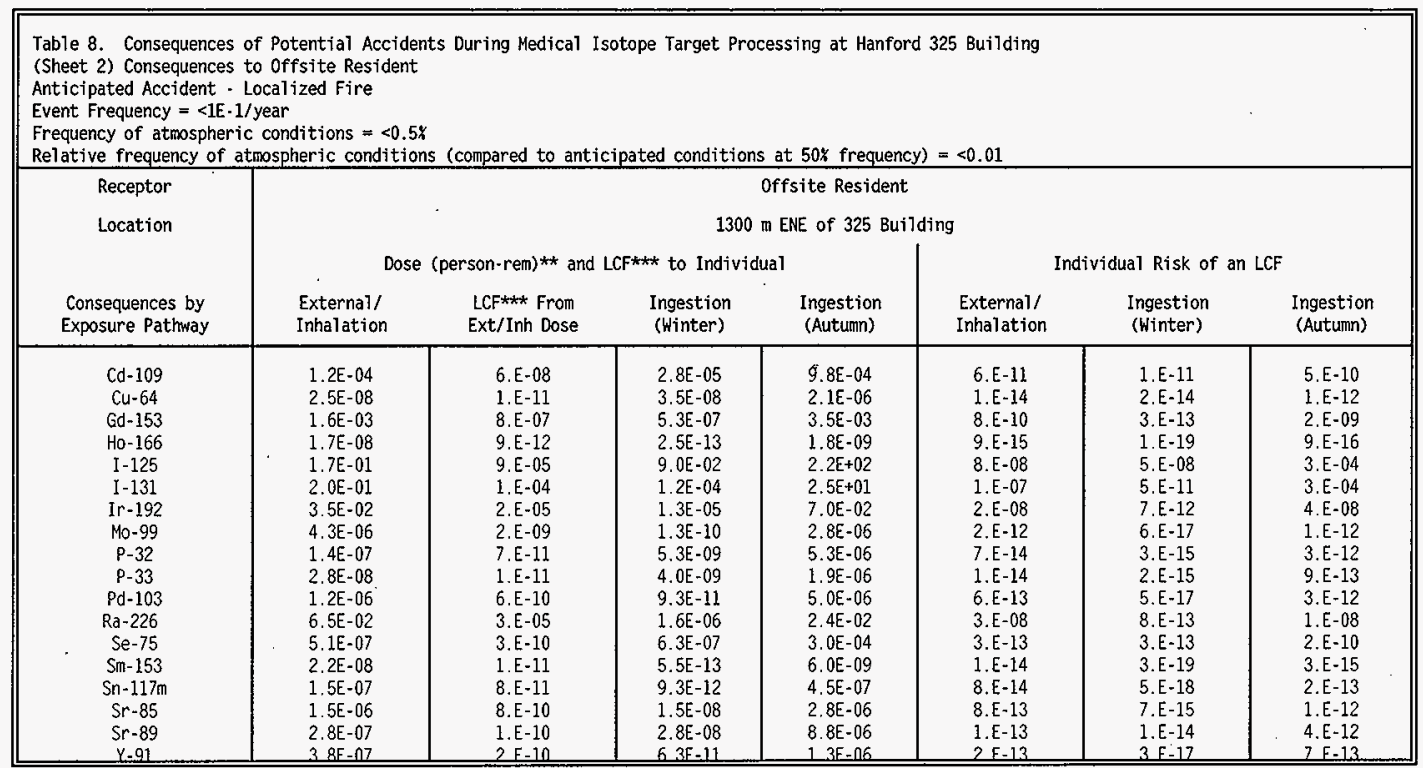

* Doses include primary product and selected impurities (some impurities were not included because they were not in the radionuclide library). Ra-226 target includes target material, selected impurities. and products Ac-227. Th-228, and Th-229.

* External/Inhalation doses include the inhalation, air submersion. and ground surface external dose pathways. They assume exposure to the entire plume with no protective action. Doses from ingestion of contaminated food products are reported separately and assume no interdiction of contaminated food. Ingestion doses are reported by season when the event occurs to reflect the range of possible consequences that might result (minimurn = Winter; maximum $=$ Autumn)

*** LCF assuming the accident occurred. i.e.. not taking credit for the probability of the accident or for the frequency of the atmospheric conditions. 
HNF-1843, Rev. 0

\begin{tabular}{|c|c|c|c|c|c|c|c|}
\hline \multicolumn{8}{|c|}{$\begin{array}{l}\text { Table } 8 \text {. Consequences of Potential Accidents During Medical Isotope Target Processing at Hanford } 325 \text { Building } \\
\text { (Sheet 3) Consequences to Collective Population } \\
\text { Anticipated Accident - Localized Fire } \\
\text { Event Frequency }=<1 \mathrm{E}-1 / \text { year } \\
\text { Frequency of atmospheric conditions }=<0.5 \% \\
\text { Relative frequency of atmospheric conditions (compared to anticipated conditions at } 50 \% \text { frequency) }=<0.01\end{array}$} \\
\hline \multirow[b]{3}{*}{$\begin{array}{c}\text { Consequences by Exposure } \\
\text { Pathway }\end{array}$} & \multicolumn{7}{|c|}{ Population within $0.50 \mathrm{mi}$ from 300 Area } \\
\hline & \multicolumn{4}{|c|}{$\begin{array}{l}\text { Dose (person-rem) }{ }^{\star \star} \text { and LCF }{ }^{\star \star \star} \text { in the Collective Population } \\
\text { External/ }\end{array}$} & \multicolumn{3}{|c|}{ Risk to Collective Population (LCF) } \\
\hline & $\begin{array}{l}\text { External/ } \\
\text { Inhalation } \\
\text { Dose }\end{array}$ & $\begin{array}{l}\text { LCF**** From } \\
\text { Ext/Inh Dose }\end{array}$ & $\begin{array}{l}\text { Ingestion } \\
\text { (Winter) }\end{array}$ & $\begin{array}{l}\text { Ingestion } \\
\text { (Autumn) }\end{array}$ & $\begin{array}{l}\text { External/ } \\
\text { Inhalation }\end{array}$ & $\begin{array}{l}\text { Ingestion } \\
\text { (Winter) }\end{array}$ & $\begin{array}{l}\text { Ingestion } \\
\text { (Autumn) }\end{array}$ \\
\hline $\begin{array}{c}\text { Cd-109 } \\
\text { Cu-64 } \\
\text { Gd-153 } \\
\text { Ho-166 } \\
I-125 \\
I-131 \\
\text { Ir-192 } \\
\text { Mo-99 } \\
\text { P-32 } \\
P-33 \\
\text { Pd-103 } \\
\text { Ra-226 } \\
\text { Se-75 } \\
\text { Sm-153 } \\
\text { Sn-117m } \\
\text { Sr-85 } \\
\text { Sr-89 } \\
Y-91\end{array}$ & $\begin{array}{l}2.4 \mathrm{E}+00 \\
1.9 \mathrm{E}-04 \\
2.7 \mathrm{E}+01 \\
1.5 \mathrm{E}-04 \\
3.2 \mathrm{E}+03 \\
3.3 \mathrm{E}+03 \\
2.9 \mathrm{E}+02 \\
7.5 \mathrm{E}-02 \\
1.4 \mathrm{E}-03 \\
2.8 \mathrm{E}-04 \\
2.4 \mathrm{E}-02 \\
7.0 \mathrm{E}+02 \\
2.0 \mathrm{E}-03 \\
2.0 \mathrm{E}-04 \\
1.4 \mathrm{E}-03 \\
2.8 \mathrm{E}-04 \\
3.0 \mathrm{E}-03 \\
3.8 \mathrm{E}-03\end{array}$ & $\begin{array}{l}1 . E-03 \\
9 . E-08 \\
1 . E-02 \\
7 . E-08 \\
2 . E+00 \\
2 . E+00 \\
1 . E-01 \\
4 . E-05 \\
7 . E-07 \\
1 . E-07 \\
1 . E-05 \\
3 . E-01 \\
1 . E-06 \\
1 . E-07 \\
7 . E-07 \\
1 . E-07 \\
2 . E-06 \\
2 . E-06\end{array}$ & $\begin{array}{l}2.5 \mathrm{E}-01 \\
2.8 \mathrm{E}-04 \\
3.0 \mathrm{E}-03 \\
2.3 \mathrm{E}-09 \\
1.2 \mathrm{E}+03 \\
1.3 \mathrm{E}+00 \\
1.2 \mathrm{E}-01 \\
1.1 \mathrm{E}-06 \\
3.8 \mathrm{E}-05 \\
3.0 \mathrm{E}-05 \\
8.3 \mathrm{E}-07 \\
1.9 \mathrm{E}-02 \\
2.8 \mathrm{E}-03 \\
4.8 \mathrm{E}-09 \\
9.0 \mathrm{E}-08 \\
3.0 \mathrm{E}-05 \\
1.3 \mathrm{E}-04 \\
4.5 \mathrm{E}-07\end{array}$ & $\begin{array}{l}1.0 \mathrm{E}+01 \\
3.4 \mathrm{E}-02 \\
3.9 \mathrm{E}+01 \\
3.8 \mathrm{E}-08 \\
1.6 \mathrm{E}+06 \\
1.4 \mathrm{E}+05 \\
3.3 \mathrm{E}+02 \\
4.3 \mathrm{E}-03 \\
6.0 \mathrm{E}-02 \\
2.4 \mathrm{E}-02 \\
5.5 \mathrm{E}-02 \\
1.2 \mathrm{E}+02 \\
2.6 \mathrm{E}+00 \\
3.5 \mathrm{E}-06 \\
1.5 \mathrm{E}-03 \\
2.4 \mathrm{E}-02 \\
8.5 \mathrm{E}-02 \\
1.1 \mathrm{E}-02\end{array}$ & $\begin{array}{l}1 . E-06 \\
9 . E-11 \\
1 . E-05 \\
7 . E-11 \\
2 . E-03 \\
2 . E-03 \\
1 . E-04 \\
4 . E-08 \\
7 . E-10 \\
1 . E-10 \\
1 . E-08 \\
3 . E-04 \\
1 . E-09 \\
1 . E-10 \\
7 . E-10 \\
1 . E-10 \\
2 . E-09 \\
2 . E-09\end{array}$ & $\begin{array}{l}1 . E-07 \\
1 . E-10 \\
2 . E-09 \\
1 . E-15 \\
6 . E-04 \\
5 . E-07 \\
6 . E-08 \\
6 . E-13 \\
2 . E-11 \\
2 . E-11 \\
4 . E-13 \\
1 . E-08 \\
1 . E-09 \\
2 . E-15 \\
5 . E-14 \\
2 . E-11 \\
6 . E-11 \\
2 . E-13\end{array}$ & $\begin{array}{l}5 . E-06 \\
2 \cdot E-08 \\
2 . E-05 \\
2 . E-14 \\
8 . E-01 \\
7 . E-02 \\
2 . E-04 \\
2 . E-09 \\
3 . E-08 \\
1 . E-08 \\
3 . E-08 \\
6 . E-05 \\
1 . E-06 \\
2 . E-12 \\
8 \cdot E-10 \\
1 . E-08 \\
4 . E-08 \\
5 . E-09\end{array}$ \\
\hline
\end{tabular}

* Doses include primary product and selected impurities (some impurities were not included because they were not in the radionuclide 1 ibrary). Ra-226 target includes target material, selected impurities, and products AC-227. Th-228, and Th-229.

* External/Inhalation doses include the inhalation, air submersion, and ground surface external dose pathways. They assume exposure to the entire plume with no protective action. Doses from ingestion of contaminated food products are reported separately and assume no interdiction of contaminated food. Ingestion doses are reported by season when the event occurs to reflect the range of possible consequences that might result (minimum = Winter: maximum $=$ Autumn $)$

*** LCF assuming the accident occurred. i.e., not taking credit for the probability of the accident or for the frequency of the atmospheric conditions. 
HNF-1843, Rev. 0

\begin{tabular}{|c|c|c|c|c|}
\hline $\begin{array}{l}\text { Receptor/ } \\
\text { Location }\end{array}$ & 100 & ding & $\begin{array}{r}\mathrm{Ne} a \\
470\end{array}$ & $\begin{array}{l}\text { cess } \\
\text { ilding }\end{array}$ \\
\hline $\begin{array}{l}\text { Isotope Target (by primary } \\
\text { product except Ra-226*) }\end{array}$ & $\begin{array}{l}\text { Dose to } \\
\text { Individual } \\
\text { (rem)**LCF*** }\end{array}$ & $\begin{array}{l}\text { Individual Risk } \\
\text { of an LCF }\end{array}$ & $\begin{array}{l}\text { Dose to } \\
\text { Individual } \\
\text { (rem)**LCF*** }\end{array}$ & $\begin{array}{l}\text { Individual Risk } \\
\text { of an LCF }\end{array}$ \\
\hline $\begin{array}{c}\text { Cd-109 } \\
\text { Cu-64 } \\
\text { Gd-153 } \\
\text { Ho-166 } \\
I-125 \\
\text { I-131 } \\
\text { Ir-192 } \\
\text { Mo-99 } \\
\text { P-32 } \\
\text { P-33 } \\
\text { Pd-103 } \\
\text { Ra-226 } \\
\text { Se-75 } \\
\text { Sn-153 } \\
\text { Sn-117m } \\
\text { Sr-85 } \\
\text { Sr-89 } \\
\text { Y- }-91\end{array}$ & $\begin{array}{l}1.2 E-015 . E-05 \\
6.6 E-063, E-09 \\
1.8 E+007, E-04 \\
1.8 E-057, E-09 \\
8.1 E+003, E-03 \\
8.0 E+003, E-03 \\
2.5 E-011, E-03 \\
3.3 E-031, E-06 \\
1.4 E-046, E-08 \\
2.7 E-051, E-08 \\
1.2 E-035, E-07 \\
1.1 E+005, E-03 \\
1.1 E-044, E-08 \\
2.1 E=058, E-09 \\
1.1 E-045, E-08 \\
1.2 E-045, E-08 \\
2.9 E-041, E-07 \\
4-5 E-042, E-07\end{array}$ & $\begin{array}{l}\text { 5.E-09 } \\
\text { 3.E-13 } \\
\text { 7.E-08 } \\
\text { 7.E-13 } \\
\text { 3.E-06 } \\
\text { 3.E-06 } \\
1 . E-07 \\
1 . E-10 \\
6 . E-12 \\
1 . E-12 \\
5 . E-11 \\
5 . E-07 \\
4 . E-12 \\
8 . E-13 \\
5 . E-12 \\
5 . E-12 \\
1 . E-11 \\
\text { T.E-11 }\end{array}$ & $\begin{array}{l}1.4 E-027 . E-06 \\
8.3 E-074 . E-10 \\
1.1 E-015 . E-05 \\
2.1 E-061 . E-09 \\
9.5 E-015 . E-04 \\
9.6 E-015 . E-04 \\
2.9 E-021 . E-04 \\
4.2 E-042 . E-07 \\
1.7 E-058 . E-09 \\
3.3 E-062 . E-09 \\
1.4 E-047 . E-08 \\
1.2 E-016 . E-04 \\
1.3 E-056 . E-09 \\
2.6 E-061 . E-09 \\
1.4 E-057 . E-09 \\
1.5 E-058 . E-09 \\
3.3 E-052 . E-08 \\
5.9 E-053 . E-08\end{array}$ & $\begin{array}{l}7 . E-10 \\
4 . E-14 \\
5 . E-09 \\
1 . E-13 \\
5 . E-07 \\
5 . E-07 \\
1 . E-08 \\
2 . E-11 \\
8 . E-13 \\
2 . E-13 \\
7 . E-12 \\
6 . E-08 \\
6 . E-13 \\
1 . E-13 \\
7 . E-13 \\
8 . E-13 \\
2 . E-12 \\
3 . F-12\end{array}$ \\
\hline
\end{tabular}

* Doses include primary product and selected impurities (some impurities were not included because they were not in the radionuclide 1 ibrary). Ra-226 target includes target material. selected impurities. and products Ac-227. Th-228, and Th-229. The target is processed in four separate runs to reduce the amount of material that can be released in an accident.

** Calculated doses are for the inhalation. air submersion. and ground surface external dose pathways. They assume exposure to the entire plume and include no protective action other than evacuation after the plume passage.

*** LCF assuming the accident occurred, i.e., not taking credit for the probability of the accident or for the frequency of the atmospheric conditions 
HNF-1843, Rev. 0

\begin{tabular}{|c|c|c|c|c|c|c|c|}
\hline \multicolumn{8}{|c|}{$\begin{array}{l}\text { Table 9. Consequences of Potential Accidents During Medical Isotope Target Processing at Hanford } 325 \text { Building } \\
\text { (Sheet 2) Consequences to offsite Resident } \\
\text { Unlikely Accident - Unlikely Seismic Event or Fire } \\
\text { Event Frequency }=1 \mathrm{E}-4 \text { to } 1 \mathrm{E}-2 / \text { year } \\
\text { Frequency of atmospheric conditions }=<0.5 \% \\
\text { Relative frequency of atmospheric conditions (compared to anticipated conditions at } 50 \% \text { frequency) }=<0.01\end{array}$} \\
\hline \multirow[b]{4}{*}{$\begin{array}{c}\text { Consequences by Exposure } \\
\text { Pathway }\end{array}$} & \multirow{2}{*}{\multicolumn{7}{|c|}{$\begin{array}{l}\text { Offsite Resident } \\
1300 \mathrm{~m} \text { ENE of } 325 \text { Building }\end{array}$}} \\
\hline & & & & & & & \\
\hline & \multicolumn{4}{|c|}{ Dose (person-rem) and LCF*** to Individual } & \multicolumn{3}{|c|}{ Individuat Risk of an LCF } \\
\hline & $\begin{array}{l}\text { External/ } \\
\text { Inhalation }\end{array}$ & $\begin{array}{l}\text { LCF*** From } \\
\text { Ext/Inh Dose }\end{array}$ & $\begin{array}{c}\text { Ingestion } \\
\text { (Winter) }\end{array}$ & $\begin{array}{l}\text { Ingestion } \\
\text { (Autumn) }\end{array}$ & $\begin{array}{l}\text { External/ } \\
\text { Inhalation }\end{array}$ & $\begin{array}{c}\text { Ingestion } \\
\text { (Winter) }\end{array}$ & $\begin{array}{l}\text { Ingestion } \\
\text { (Autumn) }\end{array}$ \\
\hline $\begin{array}{c}\text { Cd-109 } \\
\text { Cu- } 64 \\
\text { Gd-153 } \\
\text { Ho-166 } \\
\text { I-125 } \\
\text { I-131 } \\
\text { Ir-192 } \\
\text { Mo-99 } \\
\text { P-32 } \\
\text { P-33 } \\
\text { Pd-103 } \\
\text { Ra-226 } \\
\text { Se-75 } \\
\text { Sm-153 } \\
\text { Sn-117m } \\
\text { Sr-85 } \\
\text { Sr-89 } \\
\text { Y-91 }\end{array}$ & $\begin{array}{l}7.1 \mathrm{E}-03 \\
1.5 \mathrm{E}-06 \\
9.3 \mathrm{E}-02 \\
1.0 \mathrm{E}-06 \\
6.8 \mathrm{E}-01 \\
7.9 \mathrm{E}-01 \\
3.5 \mathrm{E}-02 \\
2.6 \mathrm{E}-04 \\
8.3 \mathrm{E}-06 \\
1.7 \mathrm{E}-06 \\
7.2 \mathrm{E}-05 \\
6.5 \mathrm{E}-02 \\
3.0 \mathrm{E}-05 \\
1.3 \mathrm{E}-06 \\
9.2 \mathrm{E}-06 \\
9.0 \mathrm{E}-05 \\
1.7 \mathrm{E}-05 \\
2.3 \mathrm{E}-05 \\
\end{array}$ & $\begin{array}{l}4 . E-06 \\
8 . E-10 \\
5 . E-05 \\
5 . E-10 \\
3 . E-04 \\
4 . E-04 \\
2 . E-05 \\
1 . E-07 \\
4 . E-09 \\
9 . E-10 \\
4 . E-08 \\
3 . E-05 \\
2 . E-08 \\
7 . E-10 \\
5 . E-09 \\
5 . E-08 \\
9 . E-09 \\
1 . E-08 \\
\end{array}$ & $\begin{array}{l}1.7 \mathrm{E}-03 \\
2.1 \mathrm{E}-06 \\
3.2 \mathrm{E}-05 \\
1.5 \mathrm{E}-11 \\
3.6 \mathrm{E}-01 \\
4.9 \mathrm{E}-04 \\
1.3 \mathrm{E}-05 \\
7.7 \mathrm{E}-09 \\
3.2 \mathrm{E}-07 \\
2.4 \mathrm{E}-07 \\
5.6 \mathrm{E}-09 \\
1.6 \mathrm{E}-06 \\
3.8 \mathrm{E}-05 \\
3.3 \mathrm{E}-11 \\
5.6 \mathrm{E}-10 \\
8.7 \mathrm{E}-07 \\
1.7 \mathrm{E}-06 \\
3.8 \mathrm{E}-09 \\
\end{array}$ & $\begin{array}{l}5.9 \mathrm{E}-02 \\
1.2 \mathrm{E}-04 \\
2.1 \mathrm{E}-01 \\
1.1 \mathrm{E}-07 \\
9.0 \mathrm{E}+02 \\
1.0 \mathrm{E}+02 \\
7.0 \mathrm{E}-02 \\
1.7 \mathrm{E}-04 \\
3.2 \mathrm{E}-04 \\
1.1 \mathrm{E}-04 \\
3.0 \mathrm{E}-04 \\
2.4 \mathrm{E}-02 \\
1.8 \mathrm{E}-02 \\
3.6 \mathrm{E}-07 \\
2.7 \mathrm{E}-05 \\
1.7 \mathrm{E}-04 \\
5.3 \mathrm{E}-04 \\
7.8 \mathrm{E}-05 \\
\end{array}$ & $\begin{array}{l}4 . E-10 \\
8 . E-14 \\
5 . E-09 \\
5 . E-14 \\
3 . E-07 \\
4 . E-07 \\
2 . E-08 \\
1 . E-11 \\
4 . E-13 \\
8 . E-14 \\
4 . E-12 \\
3 . E-08 \\
2 . E-12 \\
7 . E-14 \\
5 . E-13 \\
5 . E-12 \\
8 . E-13 \\
1 . E-12 \\
\end{array}$ & $\begin{array}{l}8 . E-11 \\
1 . E-13 \\
2 . E-12 \\
8 . E-19 \\
2 . E-07 \\
2 . E-10 \\
7 . E-12 \\
4 . E-16 \\
2 . E-14 \\
1 . E-14 \\
3 . E-16 \\
8 . E-13 \\
2 . E-12 \\
2 . E-18 \\
3 . E-17 \\
4 . E-14 \\
8 . E-14 \\
2 . E-16 \\
\end{array}$ & $\begin{array}{c}3 . E-09 \\
6 . E-12 \\
1 . E-08 \\
5 . E-15 \\
1 . E-03 \\
1 . E-03 \\
4 . E-08 \\
8 . E-12 \\
2 . E-11 \\
6 . E-12 \\
2 . E-11 \\
1.3 E-08 \\
9 . E-10 \\
2 . E-14 \\
1 . E-12 \\
8 . E-12 \\
3 . E-11 \\
4 . E-12 \\
\end{array}$ \\
\hline
\end{tabular}

* Doses include primary product and selected impurities (some impurities were not included because they were not in the radionuclide ibrary). Ra226 target includes target material, selected impurities, and products Ac-227. Th-228. and Th-229.

** External/Inhalation doses include the inhalation, air submersion. and ground surface external dose pathways. They assume exposure to the entire plume with no protective action. Doses from ingestion of contaminated food products are reported separately and assume no interdiction of contaminated food. Ingestion doses are reported by season when the event occurs to reflect the range of possible consequences that might result (minimum = Winter; maximum $=$ Autumn )

*** LCF assuming the accident occurred. i.e. not taking credit for the probability of the accident or for the frequency of the atmospheric conditions. 
HNF-1843, Rev. 0

\begin{tabular}{|c|c|c|c|c|c|c|c|}
\hline Receptor/Location & \multicolumn{4}{|c|}{ Dose to Collective Population (person-rem)** } & \multicolumn{3}{|c|}{ Risk to Collective Population (LCF) } \\
\hline $\begin{array}{c}\text { Consequences by Exposure } \\
\text { Pathway }\end{array}$ & $\begin{array}{l}\text { External/ } \\
\text { Inhalation }\end{array}$ & $\begin{array}{l}\text { LCF*** From } \\
\text { Ext/Inh Dose }\end{array}$ & $\begin{array}{l}\text { Ingestion } \\
\text { (Winter) }\end{array}$ & $\begin{array}{l}\text { Ingestion } \\
\text { (Auturan) }\end{array}$ & $\begin{array}{l}\text { External/ } \\
\text { Inhalation }\end{array}$ & $\begin{array}{l}\text { Ingestion } \\
\text { (Winter) }\end{array}$ & $\begin{array}{l}\text { Ingestion } \\
\text { (Autumn) }\end{array}$ \\
\hline $\begin{array}{c}\text { Cd-109 } \\
\text { Cu-64 } \\
\text { Gd-153 } \\
\text { Ho-166 } \\
\text { I-125 } \\
\text { I-131 } \\
\text { Ir-192 } \\
\text { Mo-99 } \\
\text { P-32 } \\
\text { P-33 } \\
\text { Pd-103 } \\
\text { Ra-226 } \\
\text { Se-75 } \\
\text { Sm-153 } \\
\text { Sn-117m } \\
\text { Sr-85 } \\
\text { Sr-89 } \\
\text { Y-91 }\end{array}$ & $\begin{array}{l}1.4 \mathrm{E}+02 \\
1.1 \mathrm{E}-02 \\
1.6 \mathrm{E}+03 \\
8.9 \mathrm{E}-03 \\
1.3 \mathrm{E}+04 \\
1.4 \mathrm{E}+04 \\
2.9 \mathrm{E}+02 \\
4.5 \mathrm{E}+00 \\
8.3 \mathrm{E}-02 \\
1.7 \mathrm{E}-02 \\
1.4 \mathrm{E}+00 \\
7.0 \mathrm{E}+02 \\
1.2 \mathrm{E}-01 \\
1.2 \mathrm{E}-02 \\
8.3 \mathrm{E}-02 \\
1.7 \mathrm{E}-02 \\
1.8 \mathrm{E}-01 \\
2.3 \mathrm{E}-01\end{array}$ & $\begin{array}{l}7 . E-02 \\
6 . E-06 \\
8 . E-01 \\
4 . E-06 \\
6 . E+00 \\
7 . E+00 \\
1 . E-01 \\
2 . E-03 \\
4 . E-05 \\
8 . E-06 \\
7 . E-04 \\
3 . E-01 \\
6 . E-05 \\
6 . E-06 \\
4 . E-05 \\
8 . E-06 \\
9 . E-05 \\
1 . E-04\end{array}$ & $\begin{array}{l}1.5 \mathrm{E}+01 \\
1.7 \mathrm{E}-02 \\
1.8 \mathrm{E}-01 \\
1.4 \mathrm{E}-07 \\
4.8 \mathrm{E}+03 \\
4.9 \mathrm{E}+00 \\
1.2 \mathrm{E}-01 \\
6.8 \mathrm{E}-05 \\
2.3 \mathrm{E}-03 \\
1.8 \mathrm{E}-03 \\
5.0 \mathrm{E}-05 \\
1.8 \mathrm{E}-02 \\
1.7 \mathrm{E}-01 \\
2.9 \mathrm{E}-07 \\
5.4 \mathrm{E}-06 \\
1.8 \mathrm{E}-03 \\
7.5 \mathrm{E}-03 \\
2.7 \mathrm{E}-05\end{array}$ & $\begin{array}{l}6.0 \mathrm{E}+02 \\
2.0 \mathrm{E}+00 \\
2.3 \mathrm{E}+03 \\
2.3 \mathrm{E}-06 \\
6.4 \mathrm{E}+06 \\
5.6 \mathrm{E}+05 \\
3.3 \mathrm{E}+02 \\
2.6 \mathrm{E}-01 \\
3.6 \mathrm{E}+00 \\
1.4 \mathrm{E}+00 \\
3.3 \mathrm{E}+00 \\
1.2 \mathrm{E}+02 \\
1.6 \mathrm{E}+02 \\
2.1 \mathrm{E}-04 \\
9.2 \mathrm{E}-02 \\
1.4 \mathrm{E}+00 \\
5.1 \mathrm{E}+00 \\
6.3 \mathrm{E}-01\end{array}$ & $\begin{array}{l}\text { 7.E-06 } \\
6 . E-10 \\
\text { 8.E-05 } \\
\text { 4.E-10 } \\
6 . E-04 \\
\text { 7.E-04 } \\
\text { 1.E-05 } \\
\text { 2.E-07 } \\
\text { 4.E-09 } \\
\text { 8.E-10 } \\
\text { 7.E-08 } \\
\text { 3.E-04 } \\
6 . E-09 \\
6 . E-10 \\
\text { 4.E-09 } \\
\text { 8.E-10 } \\
\text { 9.E-09 } \\
1 . E-08\end{array}$ & $\begin{array}{l}7 . E-07 \\
8 . E-10 \\
9 . E-09 \\
7 . E-15 \\
2 . E-04 \\
2 . E-07 \\
6 . E-09 \\
3 . E-12 \\
1 . E-10 \\
9 . E-11 \\
2 . E-12 \\
9 . E-10 \\
8 . E-09 \\
1 . E-14 \\
3 . E-13 \\
9 . E-11 \\
4 . E-10 \\
1 . E-12\end{array}$ & $\begin{array}{l}3 . E-05 \\
1 . E-07 \\
1 . E-04 \\
1 . E-13 \\
3 . E-01 \\
3 . E-02 \\
2 . E-05 \\
1 . E-08 \\
2 . E-07 \\
7 . E-08 \\
2 . E-07 \\
6 . E-06 \\
8 . E-06 \\
1 . E-11 \\
5 . E-09 \\
7 . E-08 \\
3 . E-07 \\
3 . E-08\end{array}$ \\
\hline
\end{tabular}

* Doses include primary product and selected impurities (some impurities were not included because they were not in the radionuclide library). Ra226 target includes target material, selected impurities, and products Ac-227, Th-228, and Th-229.

** External/Inhalation doses include the inhalation, air submersion, and ground surface external dose pathways. They assume exposure to the entire plume with no protective action. Doses from ingestion of contaminated food products are reported separately and assume no interdiction of contaminated food. Ingestion coses are reported by season when the event occurs to reflect the range of possible consequences that might result (minimum = Winter: maximum $=$ Autumn).

*** LCF assuming the accident occurred, i.e., not taking credit for the probability of the accident or for the frequency of the atmospheric conditions. 
HNF-1843, Rev. 0

\begin{tabular}{|c|c|c|c|c|}
\hline \multicolumn{5}{|c|}{$\begin{array}{l}\text { Table } 10 . \text { Consequences of Potential Accidents During Medical Isotope Target Processing at Hanford } 325 \text { Building } \\
\text { (Sheet 1) Consequences to Onsite Worker and Individual at Nearest Public Access Location } \\
\text { Extremely Un1 ikely Accident } \text {. Loss of Power and Expiosion } \\
\text { Event Frequency }=1 \mathrm{E}-6 \text { to } 1 \mathrm{E}-4 / \text { year } \\
\text { Frequency of atmospheric conditions }=<0.5 \% \\
\text { Relative frequency of atmospheric conditions (compared to anticipated conditions at } 50 x \text { frequency) }=<0.01\end{array}$} \\
\hline $\begin{array}{l}\text { Receptor/ } \\
\text { Location }\end{array}$ & 100 & ding & $\begin{aligned} & N e \\
& 470\end{aligned}$ & $\begin{array}{l}\text { cess } \\
\text { ilding }\end{array}$ \\
\hline $\begin{array}{l}\text { I sotope Target (by primary } \\
\text { product except Ra-226*) }\end{array}$ & $\begin{array}{l}\text { Dose to } \\
\text { Individual } \\
\text { (rem)**LCF***}\end{array}$ & $\begin{array}{l}\text { Individual Risk } \\
\text { of an LCF }\end{array}$ & $\begin{array}{l}\text { Dose to } \\
\text { Individual } \\
\text { (rem)**LCF*** }\end{array}$ & $\begin{array}{l}\text { Individual Risk- } \\
\text { of an LCF }\end{array}$ \\
\hline $\begin{array}{c}\text { Cd-109 } \\
\text { Cu-64 } \\
\text { Gd-153 } \\
\text { Ho-166 } \\
1-125 \\
I-131 \\
\text { Ir-192 } \\
\text { Mo-99 } \\
\text { P-32 } \\
P-33 \\
\text { Pd-103 } \\
\text { Ra-226 } \\
\text { Se-75 } \\
\text { Sm-153 } \\
\text { Sn-117m } \\
\text { Sr-85 } \\
\text { Sr-89 } \\
Y-91\end{array}$ & $\begin{array}{l}7.9 \mathrm{E}+003 \cdot \mathrm{E}-03 \\
4.4 \mathrm{E}-042 . \mathrm{E}-07 \\
1.8 \mathrm{E}+007 . \mathrm{E}-02 \\
1.2 \mathrm{E}-035 \cdot \mathrm{E}-07 \\
8.1 \mathrm{E}+003 \cdot \mathrm{E}-03 \\
8.0 \mathrm{E}+003 \cdot \mathrm{E}-03 \\
1.5 \mathrm{E}+016 . \mathrm{E}-01 \\
2.2 \mathrm{E}-019 . \mathrm{E}-05 \\
9.3 \mathrm{E}-034 . \mathrm{E}-06 \\
1.8 \mathrm{E}-037 . \mathrm{E}-07 \\
7.7 \mathrm{E}-023 \cdot \mathrm{E}-05 \\
6.5 \mathrm{E}+015 \cdot \mathrm{E}-02 \\
7.2 \mathrm{E}-033 \cdot \mathrm{E}-06 \\
1.4 \mathrm{E}-036 \cdot \mathrm{E}-07 \\
7.6 \mathrm{E}-033 \cdot \mathrm{E}-06 \\
7.8 \mathrm{E}-033 \cdot \mathrm{E}-06 \\
1.9 \mathrm{E}-028 \cdot \mathrm{E}-06 \\
3.0 \mathrm{E}-021 \cdot \mathrm{E}-05\end{array}$ & $\begin{array}{l}3 . E-09 \\
2 . E-13 \\
7 . E-08 \\
5 . E-13 \\
3 . E-09 \\
3 . E-09 \\
6 . E-07 \\
9 . E-11 \\
4 . E-12 \\
7 . E-13 \\
3 . E-11 \\
5 . E-08 \\
3 . E-12 \\
6 . E-13 \\
3 . E-12 \\
3 . E-12 \\
8 . E-12 \\
1 . E-11\end{array}$ & $\begin{array}{l}9.3 E-015 . E-04 \\
5.5 E-053 . E-08 \\
1.1 E-015 . E-03 \\
1.4 E-047 . E-08 \\
9.5 E-015 . E-04 \\
9.6 E-015 . E-04 \\
1.7 E+009 . E-02 \\
2.8 E-021 . E-05 \\
1.1 E-036 . E-07 \\
2.2 E-041 . E-07 \\
9.0 E-035 . E-06 \\
8.0 E+004 . E-03 \\
8.5 E-044 . E-07 \\
1.7 E-049 . E-08 \\
9.1 E-045 . E-07 \\
1.0 E-035 . E-07 \\
2.2 E-031 . E-06 \\
3.9 E-032 . E-06\end{array}$ & $\begin{array}{l}5 . E-10 \\
3 . E-14 \\
5 . E-09 \\
7 . E-14 \\
5 . E-10 \\
5 . E-10 \\
9 . E-08 \\
1 . E-11 \\
6 . E-13 \\
1 . E-13 \\
5 . E-12 \\
4 . E-09 \\
4 . E-13 \\
9 . E-14 \\
5 . E-13 \\
5 . E-13 \\
1 . E-12 \\
2 . E-12\end{array}$ \\
\hline
\end{tabular}

* Doses include primary product and selected impurities (some impurities were not included because they were not in the radionuclide library). Ra-226 target includes target material, selected impurities. and products AC-227. Th-228, and Th-229. The target is processed in four separate runs to reduce the amount of material that can be released in an accident.

** Calculated doses are for the inhalation, air submersion, and ground surface external dose pathways. They assume exposure to the entire plume and include no protective action other than evacuation after the plume passage.

*** LCF assuming the accident occurred, i.e., not taking credit for the probability of the accident or for the frequency of the atmospheric conditions. 
HNF-1843, Rev. 0

\begin{tabular}{|c|c|c|c|c|c|c|c|}
\hline \multirow[b]{4}{*}{$\begin{array}{c}\text { Consequences by Exposure } \\
\text { Pathway }\end{array}$} & \multirow{2}{*}{\multicolumn{7}{|c|}{$\begin{array}{c}\text { Offsite Resident } \\
1300 \mathrm{~m} \text { ENE of } 325 \text { Building }\end{array}$}} \\
\hline & & & & & & & \\
\hline & \multicolumn{4}{|c|}{ Dose (person-rem)** and LCF*** to Individual } & \multicolumn{3}{|c|}{ Individual Risk of an LCF } \\
\hline & $\begin{array}{l}\text { Externa1/ } \\
\text { Inhalation }\end{array}$ & $\begin{array}{l}\text { LCF*** From } \\
\text { Ext/Inh Dose }\end{array}$ & $\begin{array}{l}\text { Ingestion } \\
\text { (Winter) }\end{array}$ & $\begin{array}{l}\text { Ingestion } \\
\text { (Autumn) }\end{array}$ & $\begin{array}{l}\text { External/ } \\
\text { Inhalation }\end{array}$ & $\begin{array}{l}\text { Ingestion } \\
\text { (Winter) }\end{array}$ & $\begin{array}{l}\text { Ingestion } \\
\text { (Autumn) }\end{array}$ \\
\hline $\begin{array}{c}\text { Cd-109 } \\
\text { Cu-64 } \\
\text { Gd-153 } \\
\text { Ho-166 } \\
I-125 \\
I-131 \\
\text { Ir-192 } \\
\text { Mo-99 } \\
P-32 \\
P-33 \\
\text { Pd-103 } \\
\text { Ra-226 } \\
\text { Se-75 } \\
\text { Sm-153 } \\
\text { Sn-117m } \\
\text { Sr- } 85 \\
\text { Sr-89 } \\
Y-91\end{array}$ & $\begin{array}{l}4.7 E-01 \\
1.0 E-04 \\
9.3 E-02 \\
7.0 E-05 \\
6.8 E-01 \\
7.9 E-01 \\
2.1 E+00 \\
1.7 E-02 \\
5.5 E-04 \\
1.1 E-04 \\
4.8 E-03 \\
4.0 E+00 \\
2.0 E-03 \\
8.7 E-05 \\
6.1 E-04 \\
6.0 E-03 \\
1.1 E-03 \\
1.5 E-03\end{array}$ & $\begin{array}{l}2 . E-04 \\
5 . E-08 \\
5 . E-05 \\
4 . E-08 \\
3 . E-04 \\
4 . E-04 \\
1 . E-03 \\
9 . E-06 \\
3 . E-07 \\
6 . E-08 \\
2 . E-06 \\
2 . E-03 \\
1 . E-06 \\
4 . E-08 \\
3 . E-07 \\
3 . E-06 \\
6 . E-07 \\
8 . E-07\end{array}$ & $\begin{array}{l}1.1 \mathrm{E}-01 \\
1.4 \mathrm{E}-04 \\
3.2 \mathrm{E}-05 \\
1.0 \mathrm{E}-09 \\
3.6 \mathrm{E}-01 \\
4.9 \mathrm{E}-04 \\
8.0 \mathrm{E}-04 \\
5.1 \mathrm{E}-07 \\
2.1 \mathrm{E}-05 \\
1.6 \mathrm{E}-05 \\
3.7 \mathrm{E}-07 \\
1.0 \mathrm{E}-04 \\
2.5 \mathrm{E}-03 \\
2.2 \mathrm{E}-09 \\
3.7 \mathrm{E}-08 \\
5.8 \mathrm{E}-05 \\
1.1 \mathrm{E}-04 \\
2.5 \mathrm{E}-07\end{array}$ & $\begin{array}{l}3.9 E+00 \\
8.3 E-03 \\
2.1 E-01 \\
7.0 E-06 \\
9.0 E+02 \\
1.0 E+02 \\
4.2 E+00 \\
1.1 E-02 \\
2.1 E-02 \\
7.4 E-03 \\
2.0 E-02 \\
1.5 E+00 \\
1.2 E+00 \\
2.4 E-05 \\
1.8 E-03 \\
1.1 E-02 \\
3.5 E-02 \\
5.2 E-03\end{array}$ & $\begin{array}{l}2 . E-10 \\
5 . E-14 \\
5 . E-09 \\
3 . E-14 \\
3 . E-10 \\
4 . E-10 \\
1 . E-07 \\
9 . E-12 \\
3 . E-13 \\
6 . E-14 \\
2 . E-12 \\
2 . E-09 \\
1 . E-12 \\
4 . E-14 \\
3 \cdot E-13 \\
3 . E-12 \\
6 . E-13 \\
8 . E-13\end{array}$ & $\begin{array}{l}6 . E-11 \\
7 . E-14 \\
2 . E-12 \\
5 . E-19 \\
2 . E-10 \\
2 . E-13 \\
4 . E-11 \\
3 . E-16 \\
1 . E-14 \\
8 . E-15 \\
2 . E-16 \\
5 . E-12 \\
1 . E-12 \\
1 . E-18 \\
2 . E-17 \\
3 . E-14 \\
6 . E-14 \\
1 . E-16 \\
\end{array}$ & $\begin{array}{l}2 . E-09 \\
4 . E-12 \\
1 . E-08 \\
4 . E-15 \\
1 . E-06 \\
1 . E-06 \\
2 . E-07 \\
6 \cdot E-12 \\
1 . E-11 \\
4 . E-12 \\
1 . E-11 \\
8 . E-08 \\
6 . E-10 \\
1 . E-14 \\
9 . E-13 \\
6 . E-12 \\
2 . E-11 \\
3 . E-12\end{array}$ \\
\hline
\end{tabular}

* Doses include primary product and selected impurities (some impurities were not included because they were not in the radionuclide library). Ra-226 target includes target material. selected imperities. and products $\mathrm{AC}-227$. Th-228, and Th-229.

* External/Inhalation doses include the inhalation. air submersion. and ground surface external dose pathways. They assume exposure to the entire plume with no protective action. Doses from ingestion of conteminated food products are reported separately and assume no interdiction of contaminated food. Ingestion doses are reported by season when the event occurs to reflect the range of possible consequences that might result (minimurn - Winter: maximum - Autum).

*** LCF assuming the accident occurred, i.e., not taking credit for the probability of the accident or for the frequency of the atmospheric conditions, 
HNF-1843, Rev. 0

\begin{tabular}{|c|c|c|c|c|c|c|c|}
\hline \multirow{3}{*}{$\begin{array}{l}\text { Receptor/Location } \\
\text { Consequences by Exposure } \\
\text { Pathway }\end{array}$} & \multicolumn{7}{|c|}{ Population within 0.50 mi from 300 Area } \\
\hline & \multicolumn{4}{|c|}{ Dose (person-rem)** and LCF*** to Collective Population } & \multicolumn{3}{|c|}{ Risk to Collective Population (LCF) } \\
\hline & $\begin{array}{l}\text { External/ } \\
\text { Inhalation }\end{array}$ & $\begin{array}{l}\text { LCFrekt From } \\
\text { Ext/Inh Dose }\end{array}$ & $\begin{array}{l}\text { Ingestion } \\
\text { (Winter) }\end{array}$ & $\begin{array}{l}\text { Ingestion } \\
\text { (Autumn) }\end{array}$ & $\begin{array}{l}\text { External/ } \\
\text { Inhalation }\end{array}$ & $\begin{array}{c}\text { Ingestion } \\
\text { (Winter) }\end{array}$ & $\begin{array}{l}\text { Ingestion } \\
\text { (Auturn) }\end{array}$ \\
\hline $\begin{array}{c}\text { Cd-109 } \\
\text { Cu-64 } \\
\text { Gd-153 } \\
\text { Ho-166 } \\
I-125 \\
I-131 \\
\mathrm{I} r-192 \\
\mathrm{Mo}-99 \\
\mathrm{P}-32 \\
\mathrm{P}-33 \\
\mathrm{Pd}-103 \\
\mathrm{Ra}-226 \\
\mathrm{Se}-75 \\
\mathrm{Sm}-153 \\
\mathrm{Sn}-117 \mathrm{~m} \\
\mathrm{Sr}-85 \\
\mathrm{Sr}-89 \\
\mathrm{Y}-91 \\
\end{array}$ & $\begin{array}{l}9.6 E+03 \\
7.5 E-01 \\
1.6 E+03 \\
6.0 E-01 \\
1.3 E+04 \\
1.4 E+04 \\
1.7 E+04 \\
3.0 E+02 \\
5.5 E+00 \\
1.1 E+00 \\
9.6 E+01 \\
4.0 E+04 \\
8.1 E+00 \\
8.0 E-01 \\
5.5 E+00 \\
1.1 E+00 \\
1.2 E+01 \\
1.5 E+01 \\
\end{array}$ & $\begin{array}{l}5 . E+00 \\
4 . E-04 \\
8 . E-01 \\
3 . E-04 \\
6 . E+00 \\
7 . E+00 \\
9 . E+00 \\
1 . E-01 \\
3 . E-03 \\
6 . E-04 \\
5 . E-02 \\
2 . E+01 \\
4 . E-03 \\
4 . E-04 \\
3 . E-03 \\
6 . E-04 \\
6 . E-03 \\
8 . E-03 \\
\end{array}$ & $\begin{array}{l}9.8 \mathrm{E}+02 \\
1.1 \mathrm{E}+00 \\
1.8 \mathrm{E}-01 \\
9.2 \mathrm{E}-06 \\
4.8 \mathrm{E}+03 \\
4.9 \mathrm{E}+00 \\
7.2 \mathrm{E}+00 \\
4.5 \mathrm{E}-03 \\
1.5 \mathrm{E}-01 \\
1.2 \mathrm{E}=01 \\
3.3 \mathrm{E}-03 \\
1.1 \mathrm{E}+00 \\
1.1 \mathrm{E}+01 \\
1.9 \mathrm{E}-05 \\
3.6 \mathrm{E}-04 \\
1.2 \mathrm{E}-01 \\
5.0 \mathrm{E}-01 \\
1.8 \mathrm{E}-03 \\
\end{array}$ & $\begin{array}{l}4.0 E+04 \\
1.3 E+02 \\
2.3 E+03 \\
1.5 E-04 \\
6.4 E+06 \\
5.6 E+05 \\
2.0 E+04 \\
1.7 E+01 \\
2.4 E+02 \\
9.6 E+01 \\
2.2 E+02 \\
8.0 E+03 \\
1.0 E+04 \\
1.4 E-02 \\
6.1 E+00 \\
9.6 E+01 \\
3.4 E+02 \\
4.2 E+01 \\
\end{array}$ & $\begin{array}{l}5 . E-06 \\
4 . E-10 \\
8 . E-07 \\
3 . E-10 \\
6 . E-06 \\
7 . E-06 \\
9 . E-06 \\
1 . E-07 \\
3 . E-09 \\
6 . E-10 \\
5 . E-08 \\
2 . E-03 \\
4 . E-09 \\
4 . E-10 \\
3 . E-09 \\
6 . E-10 \\
6 . E-09 \\
8 . E-09 \\
\end{array}$ & $\begin{array}{l}5 . E-07 \\
6 . E-10 \\
9 . E-11 \\
5 . E-15 \\
2 . E-06 \\
2 . E-09 \\
4 . E-09 \\
2 . E-12 \\
8 . E-11 \\
6 . E-11 \\
2 . E-12 \\
6 . E-10 \\
6 . E-09 \\
1 . E-14 \\
2 . E-13 \\
6 . E-11 \\
3 . E-10 \\
9 . E-13 \\
\end{array}$ & $\begin{array}{l}2 . E-05 \\
7 . E-08 \\
1 . E-06 \\
8 . E-14 \\
3 . E-03 \\
3 . E-04 \\
1 . E-05 \\
9 . E-09 \\
1 . E-07 \\
5 . E-08 \\
1 . E-07 \\
4 . E-06 \\
5 . E-06 \\
7 . E-12 \\
3 . E-09 \\
5 . E-08 \\
2 . E-07 \\
2 . E-08\end{array}$ \\
\hline
\end{tabular}

* Doses include primary product and selected impurities (some impurities were not included because they were not in the radionuclide 1 ibrary). Ra-226 target includes target material, selected impurities, and products Ac-227, Th-228, and Th-229.

* External/Inhalation doses include the inhalation, air submersion, and ground surface external dose pathways. They assume exposure to the entire plume with no protective action. Doses from ingestion of contaminated food products are reported separately and assume no interdiction of contaminated food. Ingestion doses are reported by season when the event occurs to reflect the range of possible consequences that might result (minimum $=$ Winter: maximum $=$ Autumn).

*** LCF assuming the accident occurred, i.e., not taking credit for the probability of the accident or for the frequency of the atmospheric conditions. 
HNF-1843, Rev. 0

Table 11. Consequences to Involved Workers from Accidents during Medical Isotope Processing at the Hanford Site 325 Building

\begin{tabular}{|c|c|c|c|}
\hline \multirow[b]{2}{*}{ Isotope } & \multirow{2}{*}{$\begin{array}{l}\text { Irradiation } \\
\text { Venicle }\end{array}$} & \multicolumn{2}{|c|}{ Time to Accumulate } \\
\hline & & $25 \mathrm{rem}$ & $100 \mathrm{rem}$ \\
\hline Cladding & R3 & 1. $3 \mathrm{E}+01$ & $5.0 E+01$ \\
\hline Cladding & LIV & 2. $0 \mathrm{E}-01$ & $8.1 \mathrm{E}-01$ \\
\hline P-32 & R3 & $3.0 E+04$ & $1.2 E+05$ \\
\hline$P-33$ & LIV & 1. $4 \mathrm{E}+06$ & $5.5 E+06$ \\
\hline Au-198 & R3 & $5.2 E+02$ & $2.1 E+03$ \\
\hline$c d-109$ & LIV & $5.6 E+02$ & $2.2 \mathrm{E}+03$ \\
\hline $\mathrm{Cu}-64$ & R3 & $6.1 E+03$ & $2.4 E+04$ \\
\hline $\mathrm{Cu}-67$ & R3 & 1. $3 E+04$ & 5. $\mathrm{IE}+04$ \\
\hline Gd-153 & LIV & 4.2E-01 & $1.7 \mathrm{E}+00$ \\
\hline Ho-166 & R3 & $4.7 E+04$ & $1.9 E+05$ \\
\hline $\mathrm{I}-125$ & GAS & 1. $2 \mathrm{E}+02$ & $4.6 E+02$ \\
\hline$[-131$ & R3 & $6.4 E \div 01$ & $2.6 \mathrm{E}+02$ \\
\hline Ir-192 & LIV & $2.5 E-01$ & $1.0 E+00$ \\
\hline Lu-177 & R3 & $1.5 E+05$ & $5.8 E+05$ \\
\hline Mo-99 & R3 & $1.2 E+01$ & $4.6 E+01$ \\
\hline OS-194 & LIV & $3.6 E+01$ & $1.4 \mathrm{E}+02$ \\
\hline Pd-103 & R3 & $2.1 E \div 04$ & $8.5 E+04$ \\
\hline Pt-195m & R3 & $7.0 E \div 04$ & $2.8 E+05$ \\
\hline Ra-226 & LIV & $3.0 E+03$ & $1.2 \mathrm{E}+04$ \\
\hline $\operatorname{Re}-186$ & $\mathrm{R} 3$ & $8.8 E \div 02$ & $3.5 E+03$ \\
\hline Sc- -47 & R3 & $6.8 \varepsilon+03$ & 2. $7 \mathrm{E}+04$ \\
\hline Se-75 & LIV & $1.2 \varepsilon+03$ & $4.9 E+03$ \\
\hline $5 m-145$ & LIV & $8.0 E \div 05$ & $3.2 \mathrm{E}+06$ \\
\hline Sm-153 & R3 & $3.0 E \div 04$ & $1.2 \mathrm{E}+05$ \\
\hline$S n-117 m$ & R3 & $1.1 E+03$ & $4.3 E+03$ \\
\hline $\mathrm{Sr}-85$ & LIV & $1.9 E+02$ & $7.6 E+02$ \\
\hline Sr-89 & LIV & $8.9 \varepsilon+05$ & $3.5 \mathrm{E}+06$ \\
\hline$W-188$ & LIV & $2.9 E+00$ & $1.2 \mathrm{E}+01$ \\
\hline $\mathrm{XE}-127$ & LIV & $5.8 \varepsilon+02$ & $2.3 \mathrm{E}+03$ \\
\hline Y-91 & LIV & $4.7 E+04$ & $1.9 \mathrm{E}+05$ \\
\hline
\end{tabular}

* Times reported for medical isotope product assemblies do not include doses from activated cladding. Doses for activated stainless steel cladding are reported separately in the table. 
HNF-1843, Rev. 0

\subsection{REFERENCES}

American Cancer Society (ACS). 1996. "Cancer Facts and Figures - 1996," American Cancer Society, Atlanta, GA.

Beck, D. M., B. A. Napier, M. J. Scott, A. G. Thurman, M. D. Davis, D. B. Pittenger, S. F. Shindle, and N. C. Batishko. 1991. Hanford Area 1990 Population and 50-year Projections. PNL-7803. Pacific Northwest Laboratory, Richland, Washington.

International Commission on Radiological Protection (ICRP). 1977. Recommendations of the International Commission on Radiological Protection. ICRP Publication 26, Annals of the ICRP, Vol. 1, No. 3, Pergamon Press, Elmsford, New York.

International Commission on Radiological Protection (ICRP). 1979-1988. Limits for Intakes of Radionuclides by Workers. ICRP Publication 30, Parts 1-4 (and supplements), Annals of the ICRP Vol. 2 (No. 3/4), Vol.4 (No. 3/4), Vol. 6 No. 2/3), Vol. 8 (No. 4), and Vol. 19 (No.4), Pergamon Press, Elmsford, New York.

International Commission on Radiological Protection (ICRP). 1986. The Metabolism of Plutonium and Related Elements. ICRP Publication 48, Annals of the ICRP Vol. 16 (No. 2/3), Pergamon Press, Elmsford, New York.

International Commission on Radiological Protection (ICRP). 1991. 1990 Recommendations of the International Commission on Radiological Protection. ICRP Publication 60, Annals of. the ICRP Vol. 21 (No. 1-3), Pergamon Press, Oxford.

Mossman, K.L., M. Goldman, F. Masse, W.A. Mills, K.J. Schiager, and R.J. Vetter. "Radiation Risk in Perspective," Health Physics Society Newsletter, Vol. 24, No. 3, March 1996.

Napier, B. A., D. L. Strenge, R. A. Peloquin, and J. V. Ramsdell. 1988. GENII-The Hanford Environmental Radiation Dosimetry Software System. PNL-6584, Vol. 1 -Conceptual Representation, Vol. 2 - Users' Manual, Vol. 3 - Code Maintenance Manual. Pacific Northwest Laboratory, Richland, Washington.

Pacific Northwest National Laboratory (PNNL). 1997. Safety Analysis Report for 325 Building. PNNL-SAR-325. Pacific Northwest National Laboratory, Richland, Washington. 
Schreckhise, R. G., K. Rhoads, J. S. Davis, B. A. Napier, and J. V. Ramsdell. 1993. Recommended Environmental Dose Calculation Methods and Hanford-Specific Parameters. PNL-3777, Rev. 2. Pacific Northwest Laboratory, Richland Washington.

U.S. Department of Energy (DOE). 1988a. External Dose-Rate Conversion Factors for Calculation of Dose to the Public. DOE/EH-0070, DOE Assistant Secretary for Environment, Safety, and Health, Washington, D.C.

U.S. Department of Energy (DOE). 1988b. Internal Dose Conversion Factors for Calculation of Dose to the Public. DOE/EH-0071, DOE Assistant Secretary for Environment, Safety, and Health, Washington, D.C.

U.S. Department of Energy (DOE). 1991. Nuclear Safety Policy. SEN-35-91. U.S. Department of Energy, Washington, D.C.

U.S. Department of Energy (DOE). 1996DOE Performance hdicators for Environment, Safety and Health. Report Period Ending March 1996 Office of Environment, Safety and Health U.S. Department of Energy, Washington, D.C. (Available on the World Wide Web at: http://www.eh.doe.gov/pi)

Worku, G., and C. A. Negin. 1995. Microshield Version 4.2 User's Manual. Grove Engineering, Inc. Rockville, Maryland. 


\begin{tabular}{|c|c|c|c|c|c|}
\hline \multicolumn{6}{|c|}{ DISTRIBUTION SHEET } \\
\hline To & \multirow{2}{*}{\multicolumn{3}{|c|}{$\begin{array}{l}\text { From } \\
\text { Pacjfic Northwest Laboratory } \\
\text { K. Rhoades }\end{array}$}} & \multicolumn{2}{|l|}{ Page 1 of 1} \\
\hline Distribution & & & & \multicolumn{2}{|c|}{$\begin{array}{l}\text { Date } \\
\text { November 19, } 1997\end{array}$} \\
\hline \multicolumn{4}{|l|}{ Project Title/Work Order } & \multicolumn{2}{|c|}{ EDT No. 619615} \\
\hline \multicolumn{4}{|c|}{$\begin{array}{l}\text { Health and Safety Consequences of Medical Isotope Processing at } \\
\text { the Hanford Site } 325 \text { Building }\end{array}$} & \multicolumn{2}{|c|}{ ECN No. N/A } \\
\hline Name & MSIN & $\begin{array}{l}\text { Text } \\
\text { With All } \\
\text { Attach. }\end{array}$ & Text Only & $\begin{array}{l}\text { Attach.I } \\
\text { Appendix } \\
\text { Only }\end{array}$ & $\begin{array}{l}\text { EDT/ECN } \\
\text { Only }\end{array}$ \\
\hline \multicolumn{6}{|l|}{ B\&W Hanford Company } \\
\hline $\begin{array}{l}\text { J. D. Briggs } \\
\text { T. M. Burke } \\
\text { S. Guttenberg } \\
\text { S. W. Hiller } \\
\text { D. M. Lucoff } \\
\text { D. L. Nielsen } \\
\text { J. N. Paglieri } \\
\text { J. E. Parker } \\
\text { P. R. Prevo } \\
\text { R. O. Zimmerman }\end{array}$ & $\begin{array}{l}G 3-42 \\
\text { N2-01 } \\
\text { N2-53 } \\
\text { N2-02 } \\
\text { N2-01 } \\
\text { N2-53 } \\
\text { N2-57 } \\
\text { N2-11 } \\
\text { N2-57 } \\
\text { N2-57 }\end{array}$ & $\begin{array}{l}X \\
X \\
X \\
X \\
X \\
X \\
X \\
X \\
X \\
X\end{array}$ & & & \\
\hline \multicolumn{6}{|c|}{ Pacific Northwest National Laboratory } \\
\hline $\begin{array}{l}\text { W. T. Farris } \\
\text { C. S. G]antz } \\
\text { D. E. Lucas } \\
\text { K. Rhoades } \\
\text { L. H. Staven } \\
\text { T. S. Tenforde }\end{array}$ & $\begin{array}{l}H 5-31 \\
K 6-80 \\
K 3-66 \\
K 3-54 \\
K 3-54 \\
P 7-52\end{array}$ & $\begin{array}{l}X \\
X \\
X \\
X \\
X \\
X\end{array}$ & & & \\
\hline $\begin{array}{l}\text { Central Files } \\
\text { Station } 22 \text { (EDT, SD Cover on } 1 \text { y) }\end{array}$ & $A 3-88$ & $x$ & & & $x$ \\
\hline
\end{tabular}

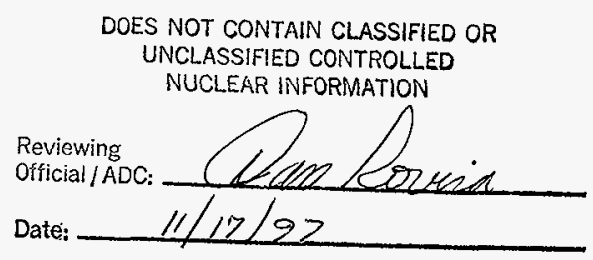

